\title{
Passende Beoordeling ten behoeve van off-bottom oesterkweek in het Lodijkse Gat, Koeiegat, Broek en Yerseksche Oesterbank van de Oosterschelde
}

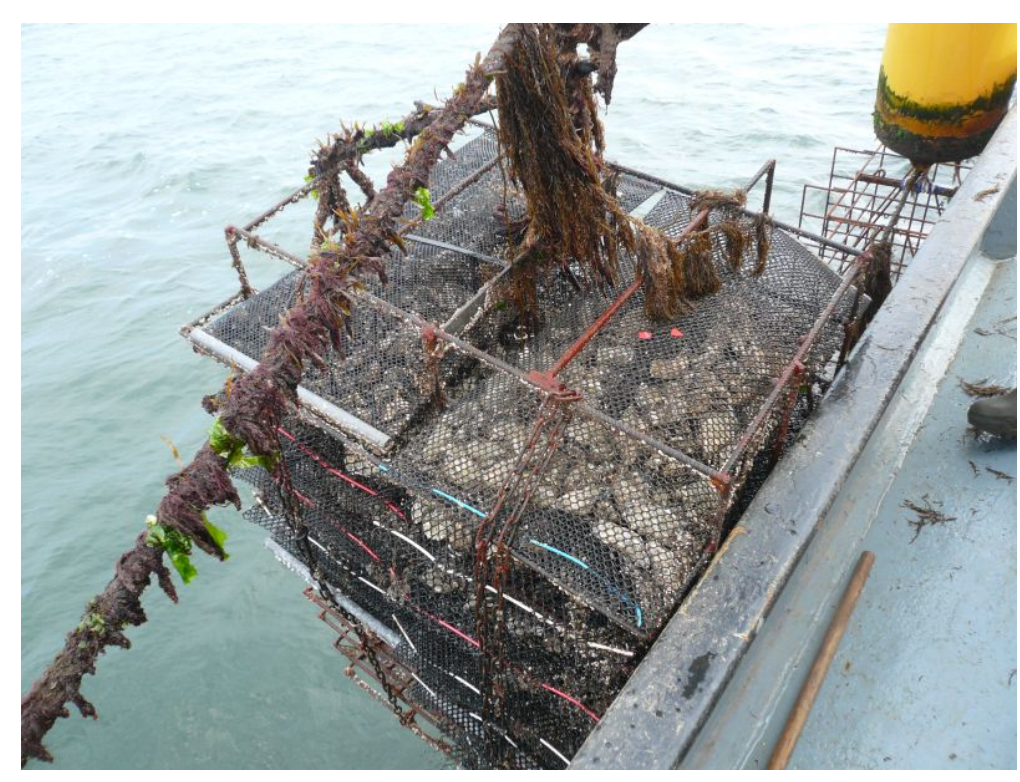

Auteur(s): $\quad$ Pauline Kamermans, Anneke van den Brink

Publicatiedatum: september 2018 
Pauline Kamermans, 2017. Passende Beoordeling ten behoeve van off-bottom oesterkweek in het Lodijkse Gat van de Oosterschelde;. Wageningen Marine Research Wageningen UR (University \& Research centre), Wageningen Marine Research rapport C064/18. 50 blz.;

Keywords: oesterteelt, Oosterschelde, aquacultuur.

Opdrachtgever: Nederlandse Oestervereniging

T.a.v.: de heer J. de Rooij

's-Gravenpolderseweg 72

4462 CH Goes

Dit rapport is gratis te downloaden van : https://doi.org/10.18174/460575

Wageningen Marine Research verstrekt geen gedrukte exemplaren van rapporten.

Wageningen Marine Research Wageningen UR is ISO 9001:2008 gecertificeerd.

Foto omslag: Pauline Kamermans

(C) 2016 Wageningen Marine Research Wageningen UR

Wageningen Marine Research, onderdeel van Stichting Wageningen Research KvK nr. 09098104,

IMARES BTW nr. NL 8113.83.696.B16.

Code BIC/SWIFT address: RABONL2U

IBAN code: NL 73 RABO 0373599285
De Directie van Wageningen Marine Research is niet aansprakelijk voor gevolgschade, noch voor schade welke voortvloeit uit toepassingen van de resultaten van werkzaamheden of andere gegevens verkregen van Wageningen Marine Research opdrachtgever vrijwaart Wageningen Marine Research van aanspraken van derden in verband met deze toepassing.

Dit rapport is vervaardigd op verzoek van de opdrachtgever hierboven aangegeven en is zijn eigendom. Niets uit dit rapport mag weergegeven en/of gepubliceerd worden, gefotokopieerd of op enige andere manier gebruikt worden zonder schriftelijke toestemming van de opdrachtgever. 


\section{Inhoud}

$\begin{array}{lc}\text { Samenvatting } & 4\end{array}$

1 Inleiding $\quad 5$

$2 \quad$ Te beoordelen activiteit $\quad 7$

$\begin{array}{lll}2.1 & \text { Locatiebepaling } & 7\end{array}$

2.2 Beschrijving van het project $\quad 9$

2.2.1 Kweekopstellingen 9

2.2.2 Markering 12

$\begin{array}{ll}2.2 .3 \text { Uitgangsmateriaal } & 12\end{array}$

$\begin{array}{lll}2.2 .4 \text { Werkwijze } & 13\end{array}$

3 Beleid $\quad 15$

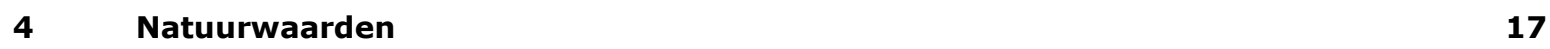

$\begin{array}{lll}4.1 & \text { Beschermde natuurwaarden en kenmerken } & 17\end{array}$

$\begin{array}{llr}4.2 & \text { Relevante beschermde natuurwaarden } & 19\end{array}$

5 Effectenanalyse $\quad 21$

$\begin{array}{lll}5.1 & \text { Verstoring van beschermde soorten } & 21\end{array}$

$\begin{array}{lll}5.2 & \text { Verontreiniging } & 21\end{array}$

5.3 Verandering dynamiek substraat $\quad 22$

5.4 Verandering soortensamenstelling 23

$\begin{array}{lll}5.5 & \text { Verlies oppervlakte } & 23\end{array}$

5.6 Vogels 24

$\begin{array}{lll}5.7 & \text { Habitatsoorten } & 26\end{array}$

$6 \quad$ Mitigerende maatregelen $\quad 27$

$\begin{array}{llr}7 & \text { Cumulatieve effecten } & 28\end{array}$

8 Conclusie $r$

$\begin{array}{lr}\text { Kwaliteitsborging } & \mathbf{3 0}\end{array}$

$\begin{array}{ll}\text { Literatuur } & 31\end{array}$

$\begin{array}{ll}\text { Verantwoording } & 33\end{array}$

$\begin{array}{lll}\text { Bijlage } 1 & \text { Factsheet triploïde oesters } & 34\end{array}$

Bijlage 2 Begeleiding OesterKweek eXperimenten (BOKX) 36

Bijlage 3 AERIUS Calculator resultaten voor het verwachte stikstofuitstoot tijdens $\begin{array}{ll}\text { werkzaamheden op deze project. } & \mathbf{3 7}\end{array}$

Bijlage 4 Vogeltellingen telgebied RWS 05532 (Broek) in de periode $2013 \mathrm{t} / \mathrm{m} 2016$. Vogeltellingen werden in de maanden maart, april, juni, juli, september en oktober maandelijks geteld (data servicedesk RWS).

Bijlage 5 Vogeltellingen telgebied RWS OS630 (Yerseksche Oesterbank) in de periode $2013 \mathrm{t} / \mathrm{m}$ 2016. Vogeltellingen werden in de maanden maart, april, juni, juli, september en oktober maandelijks geteld (data servicedesk RWS). 


\section{Samenvatting}

Sinds 2010 is aangetoond dat er in de Oosterschelde sprake is van een oester herpes virus waardoor er met name bij de jonge oesters een veel hogere sterfte optreedt. Het virus manifesteert zich bij een watertemperatuur tussen 16 en $18{ }^{\circ} \mathrm{C}$. Het virus is in 2008 in Frankrijk aangetroffen en heeft daar tot grote sterfte onder de oesters geleid. Inmiddels zijn er aanwijzingen voor toenemende resistentie tegen het virus onder de oesters in Frankrijk. Daarnaast is er voor de oesterkweek in de Oosterschelde een probleem met geïntroduceerde oesterboorders die tot grote sterfte leiden van de oesters op de kweekpercelen.

Om te komen tot herstel van de oesterproductie hebben de Nederlandse Oestervereniging (NOV) en het ministerie van Economische Zaken (nu LNV) en de Provincie Zeeland een plan van aanpak opgesteld om onder andere met behulp van voor Zeeland nieuwe technieken de problemen te beheersen. Door op verschillende locaties proeven te doen kunnen de resultaten met elkaar worden vergeleken. Een dergelijke vergelijking geeft de kwekers meer inzicht in de voor- en nadelen van het gebruik van verschillende locaties en methoden in de Oosterschelde. De nieuwe technieken hebben allemaal betrekking op off-bottom kweek. De kweekactiviteiten zullen worden begeleid door Wageningen Marine Research met onderzoek naar de effectiviteit en de effecten op de natuur.

Voor deze kweekactiviteiten met off-bottom technieken dient de gebruikelijke vergunningprocedure voor activiteiten in Natura 2000-gebieden te worden doorlopen. Onderdeel van deze procedure is dat er een Passende Beoordeling wordt uitgevoerd waarin op basis van de best beschikbare kennis en informatie wordt getoetst of de beoogde activiteit geen wezenlijk negatief effect heeft op de instandhoudingsdoelen en daarmee de kernopgaven die in het aanwijzingsbesluit voor het betreffende Natura 2000-gebied zijn geformuleerd.

De activiteiten die gerelateerd zijn aan oesterkweek op locaties Lodijkse Gat, Koeiegat, Broek en Yerseksche Oesterbank in het sublitoraal en het laagste deel van het litoraal van de Oosterschelde zijn geanalyseerd wat betreft de effecten op de instandhoudingsdoelstellingen van habitats en soorten van Natura 2000-gebied Oosterschelde. Ook is ingegaan op mitigerende maatregelen en cumulatieve effecten.

In voorliggende Passende Beoordeling is de beschikbare informatie samengevat. De conclusie is dat er geen significant negatieve effecten zijn van off-bottom oesterkweek op locaties Lodijkse Gat, Koeiegat, Broek en Yerseksche Oesterbank in het sublitoraal en laag-litoraal van de Oosterschelde. Dit geldt zowel voor de Natura 2000-instandhoudingdoelen van habitats en soorten als voor aan de orde zijnde verbeteropgaven voor het Natura 2000-gebied Oosterschelde. 


\section{$1 \quad$ Inleiding}

In de Kom van de Oosterschelde vindt de kweek van Japanse oesters (Crassostrea gigas) plaats op kweekpercelen op de bodem, voornamelijk beneden laagwater. In totaal is er 1550 ha perceelgrond uitgegeven, maar niet alle percelen zijn in gebruik. De kweek bestaat uit het invangen van oesterbroed met behulp van lege (mossel)schelpen waarop het jonge oesterbroed zich vasthecht. De schelpen worden voor de broedval uitgezaaid op broed-invang percelen en in een tijdbestek van ca 9 12 maanden opgevist en verplaatst naar percelen voor de opkweek. De opbrengst wordt geschat op 3 mln kg oesters per jaar; dit correspondeert inclusief wilde oesters met een geschatte bestandsgrootte van $9 \mathrm{mln} \mathrm{kg}$ (Kamermans \& van Asch, 2018).

Door twee recentelijk opgetreden bedreigingen zijn de oesterkwekers op zoek naar nieuwe kweekmethoden (Wijsman et al., 2015).

Sinds 2010 wordt er in de Oosterschelde een oester herpes virus aangetroffen waardoor er met name bij de jonge oesters een veel hogere sterfte optreedt. Het virus manifesteert zich bij een watertemperatuur tussen 16 en $18{ }^{\circ} \mathrm{C}$. Het virus is in 2008 in Frankrijk aangetroffen en heeft daar tot grote sterfte geleid; inmiddels zijn er aanwijzingen voor toenemende resistentie bij de oesters in Frankrijk Kamermans et al., 2013; Dundon et al., 2011).

Daarnaast is er een probleem met oesterboorders die in de Oosterschelde zijn geïntroduceerd, nl. de Japanse oesterboorder Ocenebra inornata en de Amerikaanse oesterboorder Urosalpinx cinerea (Figs. 1 en 2). De eerste meldingen van de Japanse oesterboorder dateren van 2007 (Faase \& Ligthart, 2009), maar het is mogelijk dat de slak al langer aanwezig is en niet eerder correct is gedetermineerd (Faase \& Ligthart, 2009). Van de Amerikaanse oesterboorder zijn tot nu toe alleen enkele exemplaren aangetroffen op 1 locatie in de Oosterschelde, bij Gorishoek.
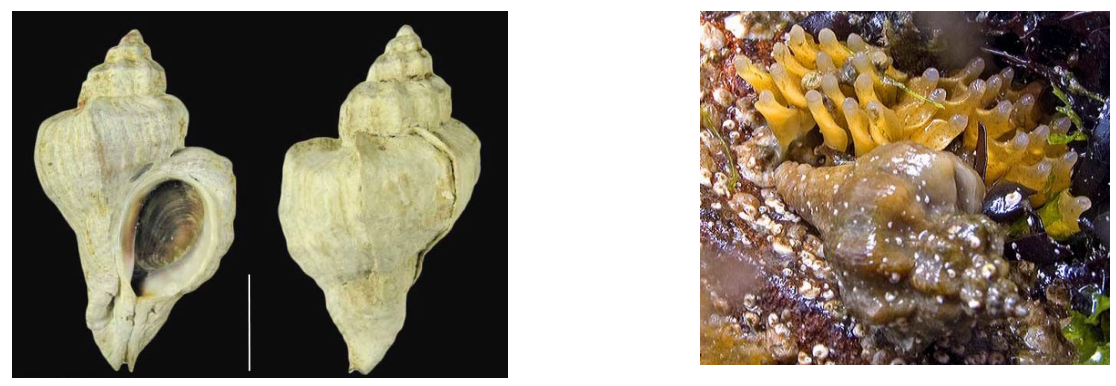

Figuur 1. Ocenebra inornata (foto: L. Schroeder, found at http://www.bily.com). Rechts: ei capsules en slak (Image: http://www.cryptosula.nl).
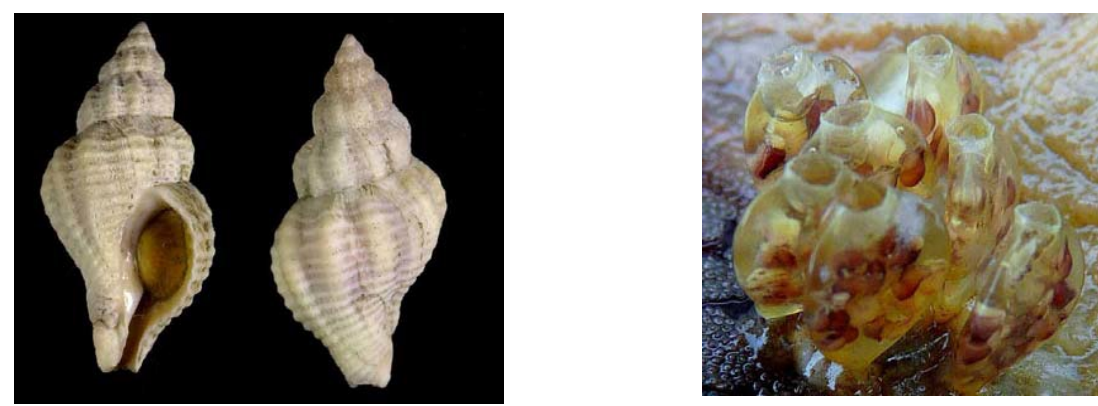

Figuur 2. Urosalpinx cinerea (foto: BISHOGAI Data Base http://shell.kwansei.ac.jp). Rechts: ei capsules met jonge slakjes nabij Gorishoek, The Netherlands (foto. A.H.M. Ligthart (Faasse \& Ligthart, 2009).

De Japanse oesterboorder is in de periode 2007 - 2013 aangetroffen in de oesterputten in Yerseke en nabij Gorishoek. Een recente inventarisatie laat zien dat de slakken nu ook worden aangetroffen in de Kom, de Dortsman, het Prinsenplaatje, de Zandkreek, de Galgenplaat en de Noordelijke tak (van Stralen et al., 2015). 
Vanuit de praktijk van de oesterkwekers wordt gemeld dat de overleving van oesterbroed sinds 2013 veel te leiden heeft van het herpesvirus. Verder worden er veel slakken en ook regelmatig ei pakketten aangetroffen op en nabij oesters, en veel schelpen met een boorgat, waardoor van de broedjes die het virus overleven vervolgens weinig terecht komt door predatie door de boorders. De combinatie van beide vijanden leidt nu tot grote problemen in de oesterkweek (Strietman et al., 2016). Om te komen tot herstel van de oesterproductie hebben de Nederlandse Oestervereniging (NOV) en het ministerie van Economische Zaken een plan van aanpak geformuleerd om onder andere met behulp van nieuwe technieken de problemen te beheersen met in acht neming van strikte randvoorwaarden t.a.v. ecologische effecten (NOV, 2016; Smaal et al., 2016). De nieuwe technieken bestaan uit off-bottom kweek.

De Oosterschelde is aangewezen als Natura 2000-gebied (Ministerie van LNV, 2009), waarvoor een beheerplan (2015 - 2021) is opgesteld (Min IenM, 2016). Het Natura 2000-gebied Oosterschelde omvat de het buitendijks gebied en een aantal aangrenzende binnendijkse gebieden, zoals de inlagen aan de zuidkust van Schouwen. Voor de nieuwe activiteit dient de gebruikelijke vergunningprocedure voor activiteiten in Natura 2000-gebieden te worden doorlopen. Onderdeel van deze procedure is dat er een Passende Beoordeling (verder PB genoemd) wordt uitgevoerd waarin op basis van de best beschikbare kennis en informatie wordt getoetst of de beoogde activiteit geen wezenlijk negatief effect heeft op de instandhoudingsdoelen en daarmee de kernopgaven die in het aanwijzingsbesluit (Ministerie van LNV, 2009) voor het betreffende Natura 2000-gebied zijn geformuleerd.

Voor off-bottom oesterkweek in het sublitoraal (zakken in kooien op de bodem of aan longlines) en in het litoraal (kweektafels en oestermanden) van de Kom van de Oosterschelde zijn door Wageningen Marine Research (WMR) Passende Beoordelingen opgesteld voor de initiatiefnemer (NOV) (Kamermans \& Smaal, 2016; Kamermans, 2016; Kamermans, 2017). Een NB wet vergunning is verleend voor het litoraal YB74/75 (kenmerk DGAN-NB / 17023443), de sublitorale locaties West van HK 10 West van HK 18, HK 10, HK 11, HK 18, YB 685 en YB 686 (kenmerk DGAN-NB / 16052053) en het sublitorale deel van percelen Windgat 13, 14 en 16 (kenmerk DGAN-NB / 17104419). De off-bottom oesterkweek activiteiten worden begeleid met onderzoek naar de effectiviteit en de effecten op de natuur. Als volgende stap op de vergunde locaties heeft de NOV het voornemen tot uitbreiding van de sublitorale locaties voor off-bottom teelt. Dit geeft de kwekers meer productiecapaciteit en inzicht in de voor- en nadelen van het gebruik van verschillende locaties in de Oosterschelde. Dit betreft zowel ervaring met de techniek als inzicht in de bedrijfseconomische aspecten.

Voorliggende PB kan door de NOV worden gebruikt bij de aanvraag, en door het bevoegd gezag (Ministerie van Economische Zaken) bij het opstellen en verlenen van de benodigde vergunning in het kader van de Natuurbeschermingswet 1998. 


\section{$2 \quad$ Te beoordelen activiteit}

\section{$2.1 \quad$ Locatiebepaling}

Leden van de Nederlandse Oester Vereniging zijn voornemens om oesters met nieuwe off-bottom technieken te gaan kweken in het Lodijkse Gat, Koeiegat, Broek en Yerseksche Oesterbank in de Oosterschelde (Fig. 3). Deze locaties zijn vrije grond (Lodijkse Gat) of oesterkweekpercelen en onverhuurde percelen (Koeiegat, Broek en Yerseksche Oesterbank). In het totaal gaat het om 134 ha geschikte oppervlak (dit is inclusief werkruimte en een veiligheidszone) (Tabel 1).

Het gebied Oosterschelde is een onderdeel van het voormalige estuarium van de Schelde. In 1986 is de Oosterschelde van de Noordzee afgesloten door een stormvloedkering. Tevens zijn er compartimenteringsdammen aangelegd om het getijvolume te beperken. Door deze deltawerken is de Oosterschelde veranderd in een ondiepe baai met zout water en gedempt getij. De huidige Oosterschelde bestaat uit een complex geheel van kreken, onder water staande zandbanken, droogvallende slikken en platen en begroeide, periodiek overstroomde schorren. Het gebied vormt, samen met binnendijkse gebieden, een bijzonder rijk leefmilieu voor flora en fauna. Vooral de ondiepe wateren en het intergetijdengebied zijn rijk aan ongewervelden, dat weer dient als voedsel voor vogels en grotere zeedieren. De dagelijks droogvallende slikken en platen van de Oosterschelde zijn van groot internationaal belang voor foeragerende watervogels, met name voor steltlopers, eendachtigen en meeuwen. De oppervlakte aan buitendijks gebied in de Oosterschelde buitendijks bedraagt 351 $\mathrm{km}^{2}$. Daarvan is $112,5 \mathrm{~km}^{2}$ intergetijdengebied. De oppervlakte van Natura 2000 -gebied Oosterschelde (inclusief binnendijkse gebieden) is $370 \mathrm{~km}^{2}$.

Als gevolg van de getijdestromen vinden erosie- en sedimentatieprocessen plaats die resulteren in een wisselend patroon van schorren, slikken en droogvallende platen (het intergetijdengebied), ondiep water en diepe getijdengeulen. In de monding van de Oosterschelde bevinden zich de diepste stoomgeulen die plaatselijk een diepte van 45 meter bereiken. Tussen deze stroomgeulen en in het gebied ten oosten van de Zeelandbrug bevinden zich uitgestrekte gebieden met ondiepe wateren met zandbanken. In het oosten en noorden van het gebied komen grote oppervlakten slikken voor. Binnendijks worden langs de oever een groot aantal karrevelden inlagen en kreekrestanten tot het gebied gerekend. Deze gebieden bestaan voornamelijk uit vochtige graslanden en open water. Het water, het intergetijdengebied en de binnendijks gelegen gebieden vormen tezamen het leefmilieu voor de rijke flora en fauna van het gebied. De grote variatie aan milieutypen in het gebied gaat gepaard met een grote diversiteit aan dier- en plantensoorten. Genoemde variatie aan milieutypen wordt bepaald door factoren als getij, stroming, watertemperatuur, hoogteligging, waterkwaliteit en sedimentsamenstelling.

Een specifiek probleem van de Oosterschelde is de zogenaamde 'zandhonger' (Van Maldegem, 2004). Door de bouw van de stormvloedkering is het morfologisch evenwicht van de Oosterschelde verstoord. Het getijvolume is verminderd en de huídige afmetingen van de geulen zijn aan deze afname nog niet aangepast. Zolang de opvulling van de geulen niet is gerealiseerd en de Oosterschelde niet haar nieuwe evenwicht heeft bereikt, zal de Oosterschelde lijden aan zandhonger. Dit heeft tot gevolg dat de platen kleiner worden en daardoor ook het gebied waar steltlopers kunnen foerageren. 


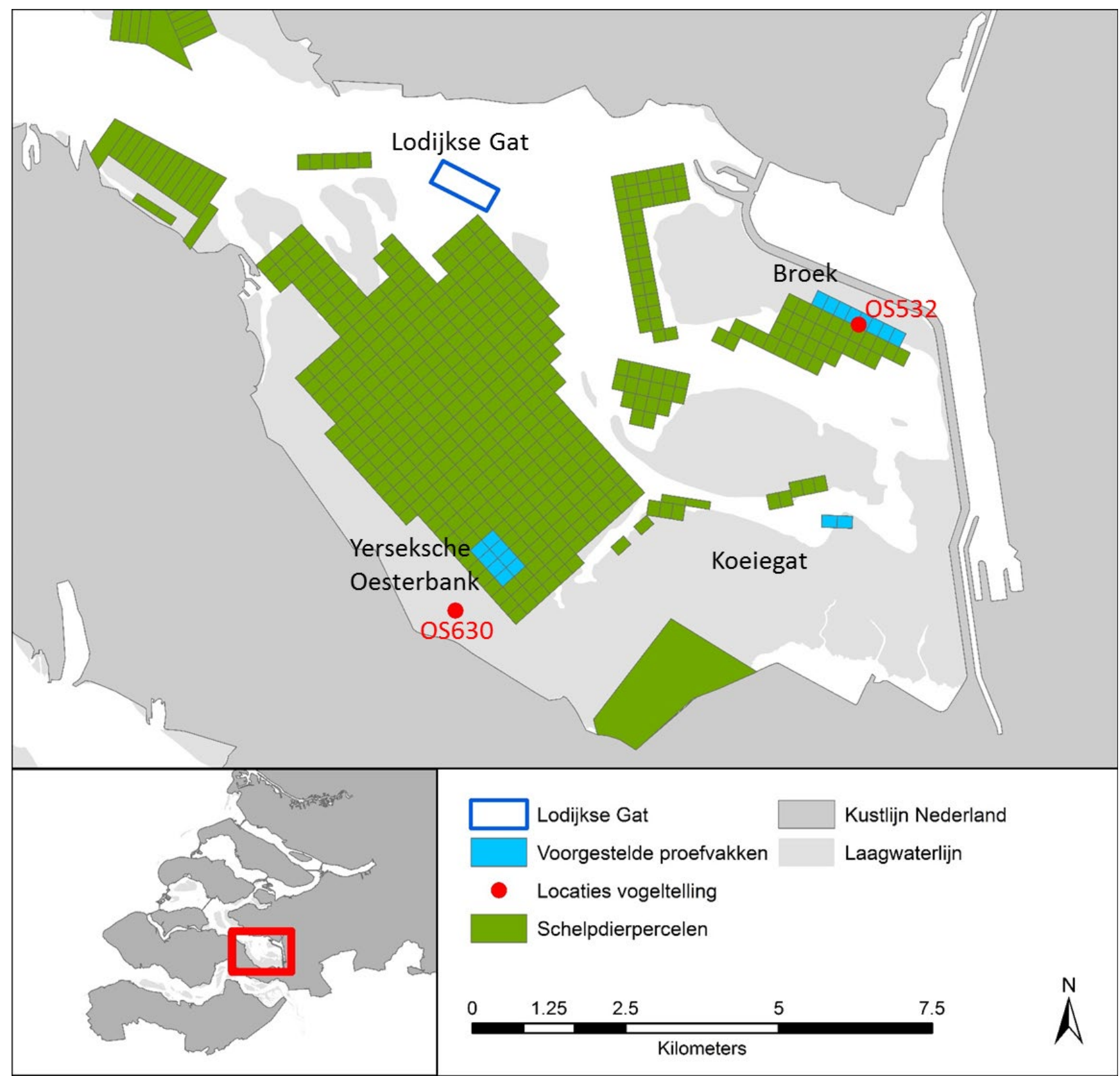

Figuur 3. Beoogde locaties voor de off-bottom oesterkweek activiteiten (Lodijkse Gat, Broek, Koeiegat en Yerseksche Oesterbank). Vogeltelgebieden van Rijkswaterstaat zijn aangegeven (OS630 en OS532).

Tabel 1. Oppervlaktes en geplande installatie types voor de vier voorgestelde locaties.

\begin{tabular}{|l|c|c|c|}
\hline \multicolumn{1}{|c|}{ Locatie } & $\begin{array}{c}\text { Oppervlakte } \\
\mathbf{( m )}\end{array}$ & $\begin{array}{c}\text { Geschikte ruimte voor off- } \\
\text { bottom oesterkweek } \\
\text { activiteit (ha) }\end{array}$ & Installatie \\
\hline Lodijkse Gat & $1000 \times 400$ & 40 & $\begin{array}{c}\text { Longlines met } \\
\text { kooien }\end{array}$ \\
\hline Koeiegat & $800 \times 400$ & 32 & Tafels \\
\hline Broek & $750 \times 400$ & 30 & Tafels \\
\hline $\begin{array}{l}\text { Yerseksche } \\
\text { Oesterbank }\end{array}$ & $1600 \times 200$ & 32 & Tafels \\
\hline
\end{tabular}

De oesterkweek activiteiten worden bij Lodijkse Gat aan longlines uitgevoerd waardoor de kweeksystemen niet te zien zijn boven water. Bij Koeiegat, Broek en Yerseksche Oesterbank zijn de installaties met laagwater kentering te zien. Bij Broek en Yerseksche Oesterbank vinden de off-bottom oesterkweek activiteiten plaats op de grens van de litorale zone. De percelen bij Broek ligt tussen 1.4/1.6 en -2.4 NAP waardoor de bovenste grens bij laag water droog kan vallen, maar de onderste 
grens alleen maar droog valt bij extreem laag water (Fig.4). De locatie bij Yerseksche Oesterbank ligt tussen -1.5/1.6 en -2.7 NAP waardoor de bovenste grens bij laag water droog kan vallen, maar de onderste grens alleen droog valt bij zelden voorkomend extreem laag water (Fig. 4). In deze gebieden zullen de kweeksystemen in de laagste delen van de percelen geplaatst worden waardoor ze alleen met extreem laag water droog zullen vallen. Als voorbeeld wordt in figuur 4 getoond dat $210 \mathrm{~cm}$ onder NAP in de periode van januari 2017 tot juni 2018 (510 dagen), maar 16 keer is droog gevallen (Fig. 4).

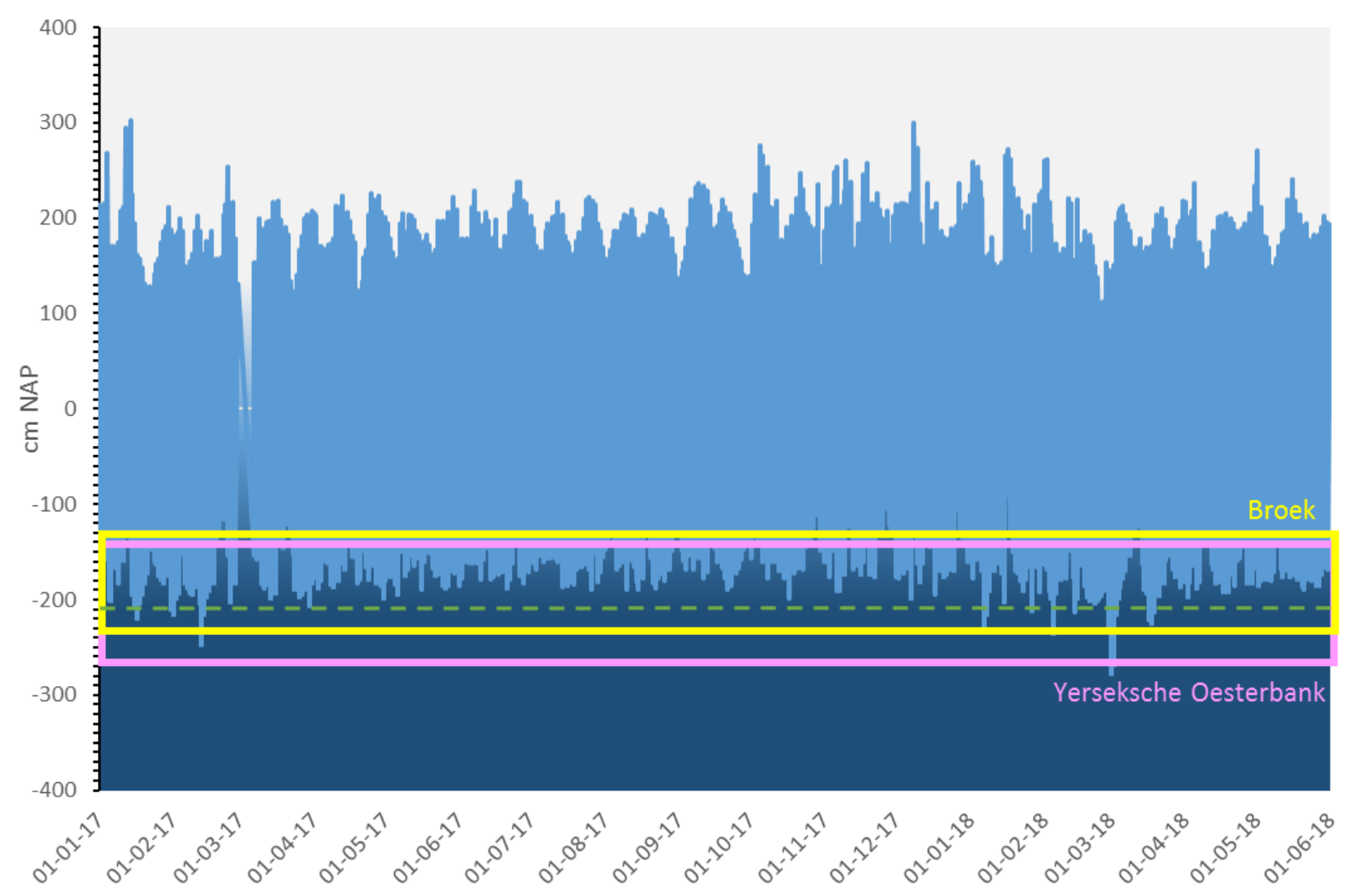

Figuur 4. Getij hoogtes in NAP (data van Rijkswaterstaat, locatie meetpaal Yerseke) en hoogtes van de twee voorgestelde droogvallende proeflocaties Broek (geel) en Yerseksche Oesterbank (paars). De gestippelde groene lijn geeft de hoogte -210 NAP aan.

\subsection{Beschrijving van het project}

\subsubsection{Kweekopstellingen}

Er worden twee verschillende systemen getest. In het sublitoraal bij Koeiegat en laaglitoraal bij Broek en Yerseksche Oesterbank betreft het tafels met oesterzakken, zoals die ook in Frankrijk worden gebruikt (Fig. 5). Kunststof zakken die zijn gevuld met oesters (Fig. 6) worden op een frame van betonijzer gelegd. De zakken worden aan het frame vastgemaakt. Een zak heeft een afmeting van ca. $100 \times 50 \mathrm{~cm}\left(0,5 \mathrm{~m}^{2}\right)$. De zakken bevatten bij oogst een verwachtte massa van $12 \mathrm{~kg}$ oesters (persoonlijke mededeling NOV leden). De zakken worden doorgaans na 5 jaar vervangen. Een tafel is 3 meter lang, $80 \mathrm{~cm}$ breed en $100 \mathrm{~cm}$ hoog en kan 6 zakken dragen. De tafels zullen in dubbele rijen in de breedte langs de laagwaterlijn van de percelen worden geplaatst. De afstand tussen de dubbele rijen is 4 meter.

Een tweede systeem is kweek in kooien die aan longlines hangen. Longlines zijn lange touwen van $200 \mathrm{~m}$ lengte die met ankers worden vastgezet op de bodem en drijvend worden gehouden met grijze drijvers zoals ook wordt gebruikt voor MZI's (Fig. 7). De lijnen voor kooien zijn van nylon en de drijvers van PE. Er is tussen de lijnen $50 \mathrm{~m}$ afstand. Aan elke longline hangen 50 kooien met oesterzakken die met een boei gemarkeerd zijn (Fig. 8). De afstand tussen de kooien is $4 \mathrm{~m}$. 
De te gebruiken installaties zijn deugdelijk van constructie. Indien overmatige slijtage van de kunststof wordt geconstateerd, worden deze binnen een maand vervangen.

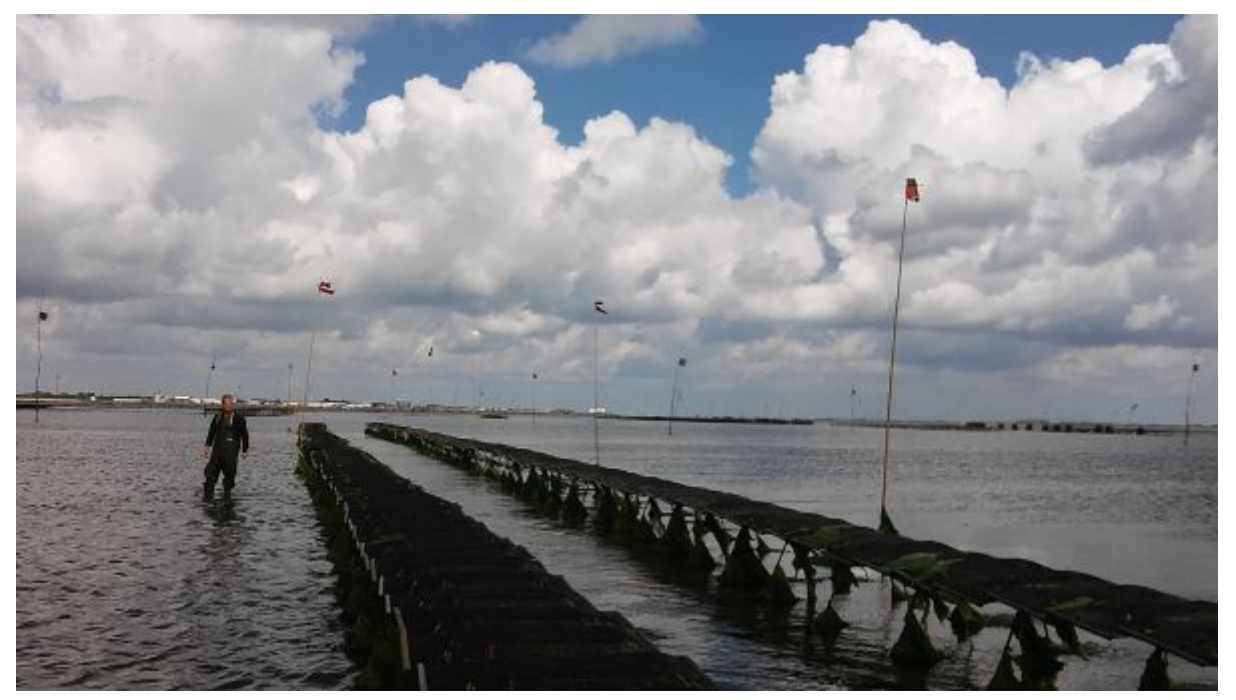

Figuur 5. Voorbeeld van off-bottom oesterkweeksystemen met zakken op tafels voor opkweek tot consumptieformaat.

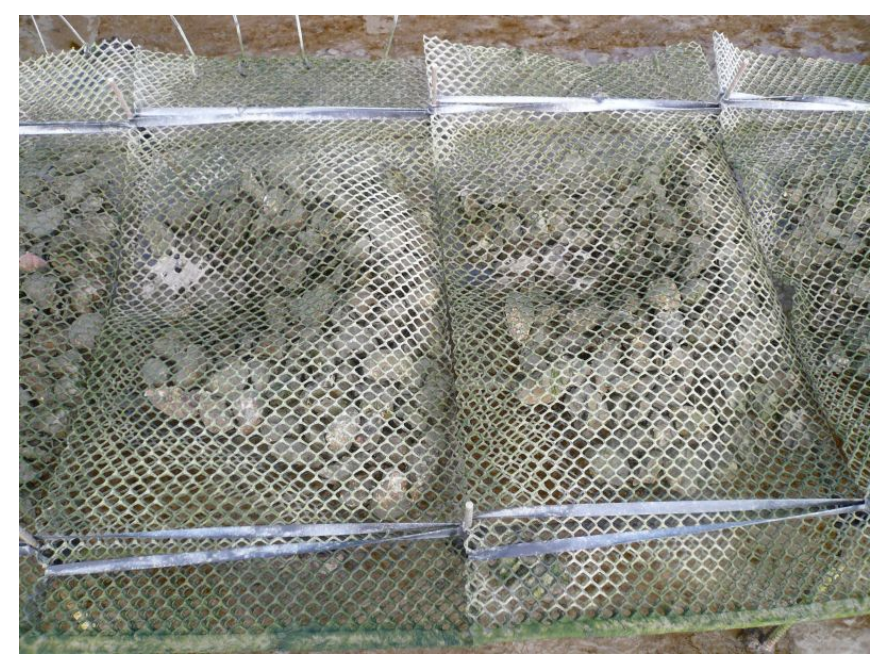

Figuur 6. Voorbeeld van oesters in oesterzakken. 


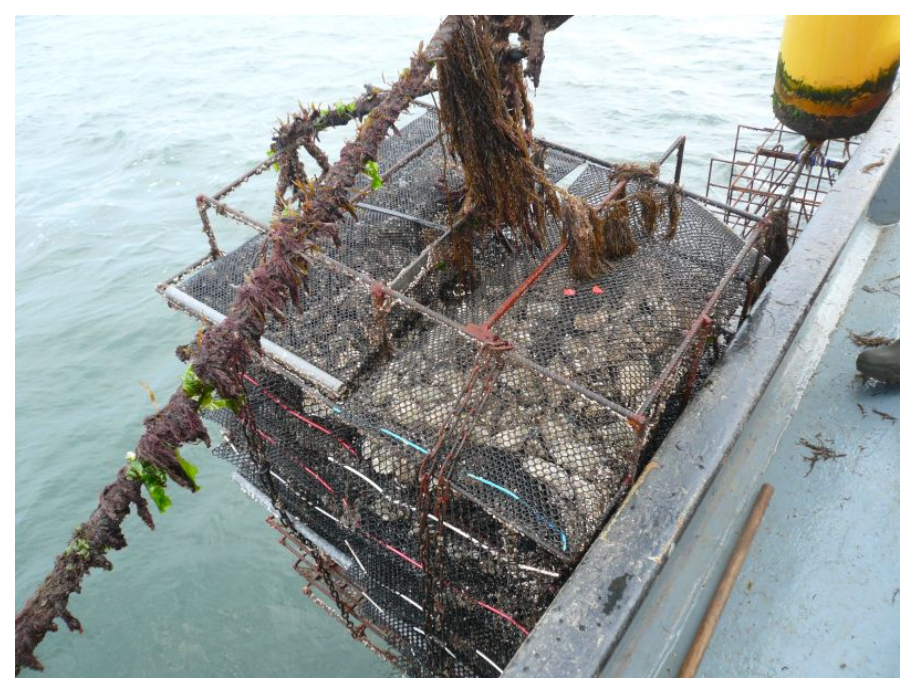

Figuur 7. Hangende kooi met oesterzakken aan longline voor off-bottom cultuur.

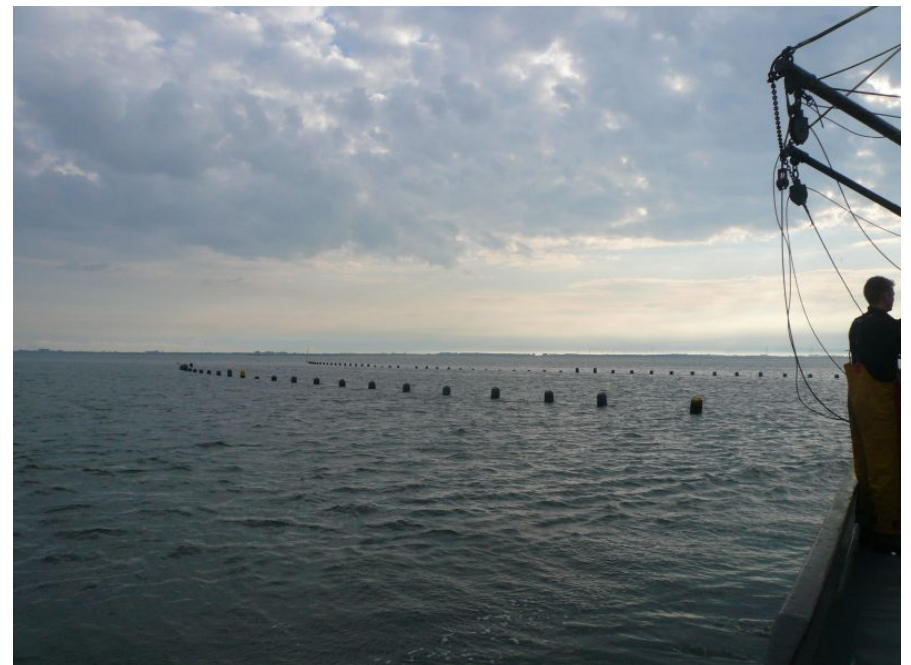

Figuur 8. Twee longlines voor off-bottom cultuur van oesters. 
Tafels en kooien zullen bij Yerseksche Oesterbank, Koeiegat en Broek gebruikt worden, en longlines bij Lodijkse Gat. Voorafgaand aan de installatie worden de percelen Yerseksche Oesterbank, Koeiegat en Broek schoon gevist. Op basis van ervaringen van kwekers wordt de totale maximale biomassa gekweekte oesters geschat voor alle vier locaties samen op ca. $400000 \mathrm{~kg}$ (Tabel 2). Ten opzichte van een geschatte biomassa aan oesters in de Kom van de Oosterschelde van $9 \mathrm{mln} \mathrm{kg}$ is dat ca. $4,5 \%$.

Tabel 2. Kweek opzet in de vier voorgestelde locaties en de geschatte biomassa aan oesters.

\begin{tabular}{|l|c|c|c|c|}
\hline & Lodijkse Gat & Koeiegat & Broek & $\begin{array}{c}\text { Yerseksche } \\
\text { Oesterbank }\end{array}$ \\
\hline Aantal rijen tafels & & 24 & 24 & 12 \\
\hline Aantal tafels per rij & & 267 & 250 & 533 \\
\hline Totaal aantal tafels & & 6408 & 6000 & 6396 \\
\hline $\begin{array}{l}\text { Kg geschatte gemiddelde } \\
\text { biomassa tafels (3kg per zak x 6 } \\
\text { zakken per tafel) }\end{array}$ & & 115344 & 108000 & 115128 \\
\hline Aantal longlines & 21 & & & \\
\hline Aantal kooien per longline & 50 & & & \\
\hline Totaal kooien & 1050 & & & $\mathbf{1 1 5} \mathbf{1 2 8}$ \\
\hline $\begin{array}{l}\text { Kg geschatte gemiddelde } \\
\text { biomassa kooien (3kg per zak x } \\
\text { 20 zakken per kooi) }\end{array}$ & 63000 & $\mathbf{1 1 5} \mathbf{3 4 4}$ & $\mathbf{1 0 8 0 0 0}$ & \\
\hline Totaal geschatte biomassa (kg) & $\mathbf{6 3 0 0 0}$ & $\mathbf{4 0 1 4 7 2}$ & \\
\hline $\begin{array}{l}\text { Totaal geschatte biomassa (kg) } \\
\text { voor alle locaties samen }\end{array}$ & & & & \\
\hline
\end{tabular}

\subsubsection{Markering}

De installaties op locatie Lodijkse Gat zullen worden gemarkeerd volgens de richtlijnen die door Rijkswaterstaat worden aangegeven. De locatie bevindt zich buiten de betonde vaargeul. De andere locaties bevinden zich op oesterpercelen en zijn met de gebruikelijke bakens gemarkeerd.

\subsubsection{Uitgangsmateriaal}

Als uitgangsmateriaal wordt oesterbroed gebruikt dat op verschillende manieren is verkregen: geproduceerd in een gecertificeerde hatchery, of ingevangen op eigen sublitorale percelen (met lege mossel schelpen of coupelles, Fig. 9), of geraapt op eigen percelen.

De hatchery oesters zijn zowel diploïde als triploïde oesters. Triploïde oesters zijn oesters van dezelfde soort als die nu gekweekt wordt (de Japanse oester Crassostrea gigas), maar dan met drie paar chromosomen in hun cellen in plaats van de normale twee paar in diploïde oesters. De productie van triploïde oesters vindt plaats door een behandeling tijdens de bevruchting in de hatchery. Door de extra set chromosomen zijn triploïde oesters steriel. Omdat geen energie wordt gebruikt voor het ontwikkelen van geslachtsorganen en -producten gaan triploïde oesters efficiënter om met hun voedsel en kunnen de oesters sneller groeien (Stanley et al., 1984). In Australië werd na 1 jaar een 1,5x hoger gewicht bereikt bij triploïde oesters (Nell \& Perkins, 2005). Daarnaast bevatten triploïde oesters voldoende vlees van goede kwaliteit in de periode dat andere oesters paaien en gewicht verliezen (Nell \& Perkins, 2005; Boudry, 2008). Dit zorgt ervoor dat triploïde oesters ook in de zomer verkocht kunnen worden. Ook zijn triploïde oesters beter resistent tegen stressvolle condities (Garnier-Gere et al., 2002) en vertonen ze een lagere sterfte (Gagnaire et al., 2006). De methode is niet nieuw. In Frankrijk is $30 \%$ van de oesters triploïd (Robert et al., 2012). Er zijn verschillende methoden om triploïde oesters te produceren. Als oesters triploïde zijn gemaakt door fysiologische 
modificatie ("chemisch geïnduceerd") kan er sprake zijn van onvolledige triploïdie (Lapègue et al., 2008). Een beperkt gedeelte van deze oesters zijn dan terug veranderd in normale diploïde oesters. Als oesters vanuit een tetraploïde en een diploïde ouder zijn gemaakt ("natuurlijk") kunnen ze niet terug veranderen naar diploïde oesters (Guo et al., 1996). Tetraploïde oesters worden in een hatchery gemaakt, genetisch gecheckt om te zien of de behandeling succesvol was en daar in quarantaine gehouden in een gecertificeerd quarantaine station en komen dus niet terecht in de Oosterschelde. Voor triploïde nakomelingen is een kruising van een diploïde en een tetraploïde ouder nodig. Deze kruising vindt in een aparte ruimte van de hatchery plaats, waarna de tetraploïde oesters weer terug gaan in quarantaine. Zie ook bijlage 1 (Kamermans, 2015).

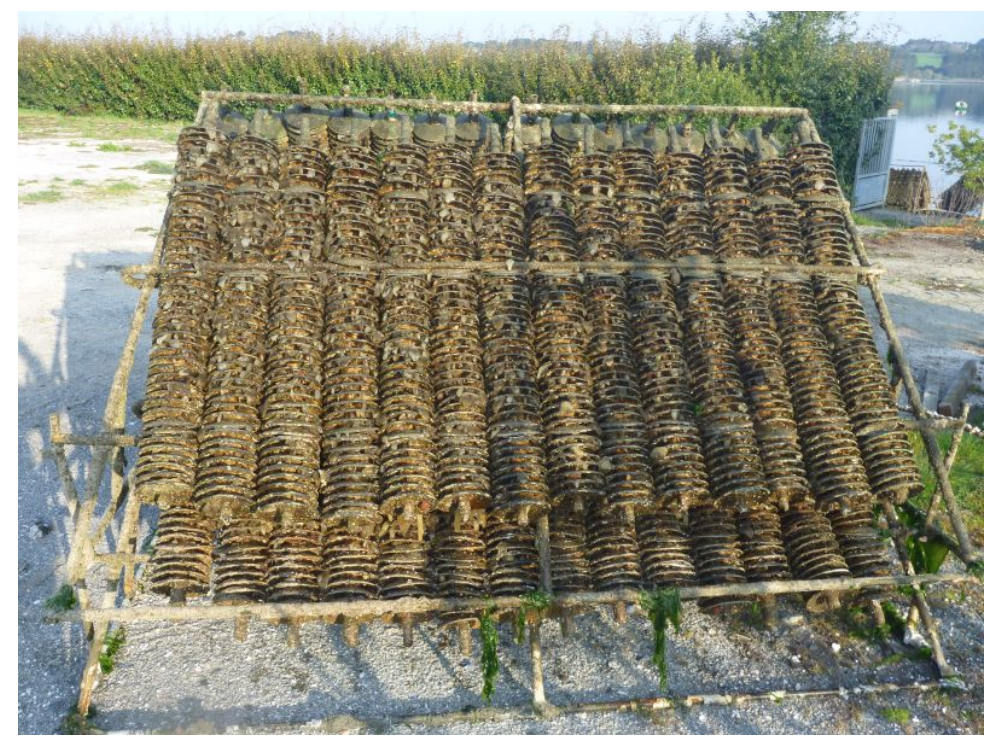

Figuur 9. Voorbeeld van coupelles waarmee oesterbroed wordt ingevangen.

\subsubsection{Werkwijze}

Voor het plaatsen van de installaties wordt er vanaf een oesterschip rondom hoogwater bij de sublitorale locaties en rondom twee uur voor laagwater bij de laag-litoraal locaties gewerkt. Er wordt niet gewerkt op de dagen met zulk laag water dat de laag-litorale locaties droogvallen (zie 2.1). In april worden de kweekinstallaties geplaatst. Verwacht wordt dat de oesters regelmatig moeten worden uitgedund. Tevens zullen de zakken periodiek moeten worden omgekeerd om de aangroei van algen te voorkomen en worden opgeschud om de groeiranden van de oesters te beschadigen, zodat de oester een mooie diep-bolle vorm krijgt. Bij Lodijkse Gat en Koeiegat zullen deze onderhoudsactiviteiten aan boord van een schip uitgevoerd worden, bij Broek en Yerseksche Oesterbank zal dit bij laag water, wadend door het water, op de locatie uitgevoerd worden.

In de periode van januari - november wordt verwacht dat er één maal per 2 weken gedurende 2 - 3 uur (afhankelijk van het aantal zakken) activiteiten zullen zijn. Op die dagen zal een deel van de zakken worden gesorteerd en opnieuw opgezakt. Bij het opnieuw plaatsen, worden de zakken gekeerd en wordt onderhoud gepleegd aan de tafels. De zakken worden voor $1 / 3 \mathrm{e}$ deel gevuld met kleine oesters. Zodra deze zover zijn opgegroeid dat de helft van de zak is gevuld, wordt een deel overgebracht in een lege zak, zodat de zak opnieuw voor $1 / 3 \mathrm{e}$ is gevuld. Dat proces herhaalt zich totdat de oesters de consumptiegrootte hebben bereikt. In de periode september tot en met mei, maar met een piek in de periode november tot half december zullen de oesters die groot genoeg zijn worden geoogst ten behoeve van de verkoop. In de oogstperiode november - half december zal er meerdere dagen per week gedurende 2 - 4 uur per dag activiteit zijn. De activiteiten zijn samengevat in Tabel 3. Op de locatie zal het schip stil liggen om de werkzaamheden aan de kooien en tafels te kunnen uitvoeren.

Gebaseerd op het totaal aantal tafels en kooien uit tabel 2 is uitgegaan van 3 kwekers die elk 10 dagen per 2 weken nodig hebben voor het uitvoeren van onderhoud aan de tafels, kooien en longlines. 
De verwachting is dat in één dag bij hoogwater werk kan worden uitgevoerd bij een sublitorale locatie, en dat diezelfde dag bij laagwater een litoraal locatie bezocht kan worden.

Tabel 3. Activiteiten op oesterpercelen

\begin{tabular}{|c|c|c|c|c|}
\hline \multirow[b]{2}{*}{ Activiteit } & \multirow[b]{2}{*}{ Frequentie } & \multicolumn{2}{|c|}{ Tijdsduur en tijdstip } & \multirow[b]{2}{*}{ Periode } \\
\hline & & Lodijkse Gat en & $\begin{array}{c}\text { Broek, Yerseksche } \\
\text { Oesterbank en } \\
\text { Koeiegat }\end{array}$ & \\
\hline $\begin{array}{l}\text { Plaatsen } \\
\text { kweekinstallaties }\end{array}$ & $\begin{array}{l}\text { eenmalig in eerste } \\
\text { jaar }\end{array}$ & 6 uur bij daglicht & $\begin{array}{l}6 \text { uur bij daglicht } \\
\text { rondom laagwater }\end{array}$ & april \\
\hline $\begin{array}{l}\text { Aangroei verwijderen; } \\
\text { Opschudden; } \\
\text { Onderhoud } \\
\text { kweekinstallaties }\end{array}$ & $\begin{array}{l}\text { één maal per } 2 \\
\text { weken over het jaar }\end{array}$ & 2-3 uur bij daglicht & $\begin{array}{l}2-4 \text { uur bij daglicht } \\
\text { rondom laagwater }\end{array}$ & $\begin{array}{l}\text { augustus - } \\
\text { november }\end{array}$ \\
\hline Oogst periode & één maal per jaar & 2-4 uur bij daglicht & $\begin{array}{l}2-4 \text { uurbij daglicht } \\
\text { rondom laagwater }\end{array}$ & $\begin{array}{l}\text { september } \mathrm{t} / \mathrm{m} \\
\text { mei }\end{array}$ \\
\hline $\begin{array}{l}\text { Belangrijkste oogst } \\
\text { periode }\end{array}$ & 3 dagen per week & 2-4 uur bij daglicht & $\begin{array}{l}2-4 \text { uurbij daglicht } \\
\text { rondom laagwater }\end{array}$ & $\begin{array}{l}\text { november - } \\
\text { december }\end{array}$ \\
\hline $\begin{array}{l}\text { Opruimen } \\
\text { kweekinstallaties }\end{array}$ & $\begin{array}{l}\text { eenmalig in laatste } \\
\text { jaar }\end{array}$ & 6 uur bij daglicht & $\begin{array}{l}6 \text { uur bij daglicht } \\
\text { rondom laagwater }\end{array}$ & juni \\
\hline
\end{tabular}




\section{Beleid}

\section{Beleidsbesluit schelpdiervisserij}

Door de minister van LNV wordt in het Beleidsbesluit Schelpdiervisserij 2005-2020 (Ministerie van LNV, 2004) ruimte gegeven om te experimenteren met alternatieve en duurzame nieuwe kweekvormen. In het Beleidsbesluit 2005-2020 is met betrekking tot de kweek van schelpdieren (hfdst 4.3) het navolgende opgenomen:

Initiatieven om ook andere soorten zoals St. Jacobsschelpen, Venusschelpen en Japanse oesters te kweken zullen op hun inpasbaarheid binnen de bestaande kaders worden beoordeeld. Op voorhand wordt vanuit een positieve grondhouding naar dit soort initiatieven gekeken. Nieuwe kweekvormen mogen vooraleerst alleen onder experimentele omstandigheden (kleinschalig en begeleid door onderzoek) plaatsvinden.

Een experiment met het op een alternatieve wijze kweken van schelpdieren past derhalve in het beleid van de minister van EZ. Voorwaarde is wel dat het duurzaam is, kleinschalig, passend binnen de natuurlijke mogelijkheden en wordt begeleid door onderzoek.

Om de recente problemen in de oesterkweek gezamenlijk het hoofd te kunnen bieden, wordt de komende periode ingezet op maatregelen voor de korte termijn, de middellange en lange termijn zoals beschreven in Plan van Aanpak 'Oester-maatregelen' 2016 - 2018 (NOV, 2016). Om de oesterboorder te ontlopen valt in eerste instantie te denken aan het invangen en kweken in de waterkolom ("off-bottom"). Off-bottom-technieken die hiervoor in aanmerking komen zijn:

- Mandjes, die met name in het litoraal kunnen worden gebruikt (kan eventueel ook in het sublitoraal). - Rekken en tafels, waarop zowel in het litoraal als in het sublitoraal zakken met oesters worden gelegd voor verdere opkweek. Met deze technieken is in de Nederlandse wateren nog weinig ervaring opgedaan, zodat aan de hand van nadere experimenten meer informatie wordt verkregen over de consequenties met betrekking tot onder meer 'lichtinval', 'schaduwwerking' en 'leefgebied en soorten'.

- Staande kweekkooien, die op de bodem in zowel het litoraal als het sublitoraal kunnen worden geplaatst. Ook bij deze technieken kan aan de hand van experimenten meer informatie worden verkregen over de consequenties met betrekking tot onder meer 'lichtinval', 'schaduwwerking' en 'leefgebied en soorten'.

- Hangende kweekkooien, die in het sublitoraal aan longlines zijn bevestigd.

\section{Natura 2000}

De Oosterschelde is op 23 december 2009 door de minister van Landbouw, Natuur en Voedselkwaliteit (LNV) definitief aangewezen als Natura 2000-gebied (gebiedsnummer 118: Oosterschelde). Met het oog op deze aanwijzing, dienen activiteiten die als plan of project volgens art. 6:3 van de Habitatrichtlijn (richtlijn 92/43IEEG) kunnen worden aangemerkt, te worden beoordeeld op hun effecten op de instandhoudingdoelstellingen van het gebied. 


\section{Beheerplan Deltawateren}

Via dit beheerplan (Van Bentum \& Koolmees, 2014; Ministerie IenM, 2016) is de oesterteelt onder specifieke voorwaarden vrijgesteld van de $\mathrm{Nb}$-wet vergunningplicht. De oesterhangcultuur en de experimentele oesterkweek met diverse methoden blijft echter een vergunningplichtige activiteit. De oesterkweek vindt plaats op daartoe bestemde oesterpercelen in de Oosterschelde die door het Rijk worden verhuurd.

\section{Vooronderzoek ten behoeve van de passende beoordeling ex artikel 6 lid 3 Habitatrichtlijn}

Het project bestaat uit het opkweken van oesters met behulp van zakken in het Natura 2000-gebied Oosterschelde, volgens de hierboven omschreven werkwijze. Uitvoering van het onderhavige project betreft een activiteit welke niet direct verband houdt met, of nodig is voor het beheer van het Vogelen Habitatrichtlijngebied Oosterschelde.

Artikel 6, derde lid, van de Habitatrichtlijn bevat een toetsingskader voor plannen en projecten in of nabij de op grond van de Habitatrichtlijn beschermde gebieden en, via de schakelbepaling van artikel 7 van de Habitatrichtlijn, de op grond van de Vogelrichtlijn beschermde gebieden. Rechtstreekse werking van de Vogel- en Habitatrichtlijn (VHR) geldt alleen voor de aangemelde, maar nog nietaangewezen gebieden. Omdat de VHR volgens EU goed in de nationale wetgeving is opgenomen, geldt de Natuurschermingswet als kader. In artikel 6, derde lid, van de Habitatrichtlijn is bepaald dat voor elk plan of project dat niet direct verband houdt met of nodig is voor het beheer van een op grond van deze richtlijn beschermd gebied en afzonderlijk of in combinatie met andere plannen of projecten significante gevolgen kan hebben voor dat gebied, een analyse van de gevolgen voor dat gebied moet worden gemaakt. Hierbij dient rekening te worden gehouden met de instandhoudingsdoelstellingen van dat gebied en geldt dat de bevoegde nationale instanties slechts toestemming voor het betrokken plan of project geven nadat zij op basis van de analyse de zekerheid hebben verkregen dat de natuurlijke kenmerken van het betrokken gebied (met het oog waarop het gebied is aangewezen) niet zullen worden aangetast.

Ten behoeve van deze PB is gekeken naar die soorten en habitattypen welke als kwalificerend zijn aangemerkt met betrekking tot de, binnen de Oosterschelde aangewezen en vastgestelde, Vogel- en Habitatrichtlijngebieden. 


\section{$4 \quad$ Natuurwaarden}

\subsection{Beschermde natuurwaarden en kenmerken}

Het Natura 2000-gebied de Oosterschelde heeft een totaal oppervlak van 36980 ha en bevat zowel een buitendijks als een binnendijks (inlagen, karrevelden, kreekrestanten, eendenkooien) gebied (Ministerie van LNV, 2009). De Oosterschelde is een voormalig estuarium dat in 1986 is afgesloten van de Noordzee door middel van de Oosterscheldekering. Tevens zijn er compartimenteringsdammen aangelegd om het getijvolume te beperken. Door deze Deltawerken is de Oosterschelde veranderd van een estuarium naar een ondiepe baai met zout water en gedempt getij. De droogvallende slikken en platen vormen een belangrijk onderdeel van de getijdennatuur in Zuidwest Nederland.

De huidige Oosterschelde bestaat uit een complex geheel van geulen, onder water staande zandbanken, droogvallende slikken en platen en hoger gelegen schorren. Het gehele aquatische gebied wordt gerekend tot het habitattype $\mathrm{H} 1160$ (Grote, ondiepe kreken en baaien, verkorte naam Grote baaien), terwijl de habitattypen buitendijkse schorren (H1330A), slijkgrasvelden (H1320) en zilte pionierbegroeiingen (H1310A) apart zijn aangewezen (Janssen \& Schaminée, 2009). De Oosterschelde is een belangrijk leefgebied voor kustbroedvogels, moerasbroedvogels en doortrekkende en overwinterende watervogels. De Oosterschelde is voor een tweetal habitatsoorten aangewezen: de Gewone zeehond (H1365) en de Noordse woelmuis (H1340).

In het doelendocument (Troost \& Van Hulzen, 2009) is voor de Oosterschelde een aantal kernopgaven geformuleerd:

- Behoud van slikken en platen voor rustende en foeragerende niet-broedende vogels en rustgebieden voor zeehonden;

- Behoud en herstel van schorren en zilte graslanden (buitendijks) met alle successiestadia, zoet-zout overgangen, verscheidenheid in substraat en getijregime en als hoogwatervluchtplaats;

- Behoud en ontwikkeling van kwaliteit binnendijkse brakke gebieden voor Noordse woelmuis en voor broedvogels (Kluut, sterns) en als hoogwatervluchtplaats, overgangs- en trilvenen

(veenmosrietlanden) brakke variant van ruigten en zomen (Harig wilgenroosje), schorren en zilte graslanden (binnendijks) en als hoogwatervluchtplaats.

Deze kernopgaven zijn in het aanwijzingsbesluit Oosterschelde (Ministerie van LNV, 2009) vertaald in een aantal instandhoudingsdoelen (Tabel 4). 
Tabel 4. Lijst met habitattypen en soorten waarvoor de Oosterschelde is aangewezen, met bijhorende instandhoudingsdoelstellingen. =: behoud doelstelling omvang en kwaliteit. >:

uitbereidingsdoelstelling areaal of verbeterdoelstelling kwaliteit (Ministerie van LNV, 2009). *Voor de Gewone zeehond is een regionaal doel gesteld van ten minste 200 exemplaren in het Deltagebied (Ministerie van LNV, 2009).

\begin{tabular}{|c|c|c|c|c|}
\hline & & \multicolumn{3}{|c|}{ Gebiedsdoelstelling } \\
\hline & & 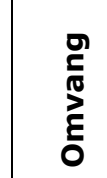 & 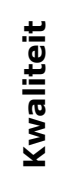 & $\begin{array}{l}\frac{0}{2} \\
\frac{\pi}{3} \\
\frac{0}{0} \\
0 \\
0\end{array}$ \\
\hline Code & Habitattypen & & & \\
\hline H1160 & Grote baaien & $=$ & $>$ & \\
\hline H1310A & Zilte pionierbegroeiingen(zeekraal) & $>$ & $=$ & \\
\hline H1320 & Slijkgrasvelden & $=$ & $=$ & \\
\hline H1330A & Schorren en zilte graslanden (buitendijks) & $=$ & $=$ & \\
\hline H1330B & Schorren en zilte graslanden (binnendijks) & $>$ & $=$ & \\
\hline H7140B & Overgangs- en trilvenen (veenmosrietlanden) & $>$ & $>$ & \\
\hline & Soorten & & & \\
\hline $\mathrm{H} 1340$ & Noordse woelmuis & $>$ & $=$ & $>$ \\
\hline H1365 & Gewone zeehond & $=$ & $>$ & $>$ \\
\hline & Broedvogels & & & paren \\
\hline A132 & Kluut & $=$ & $=$ & 2000 \\
\hline A137 & Bontbekplevier & $=$ & $=$ & 100 \\
\hline A138 & Strandplevier & $>$ & $>$ & 220 \\
\hline A191 & Grote stern & $=$ & $=$ & 4000 \\
\hline A193 & Visdief & $=$ & $=$ & 6500 \\
\hline A194 & Noordse stern & $=$ & $=$ & 20 \\
\hline A195 & Dwergstern & $=$ & $=$ & 300 \\
\hline & Niet-broedvogels & & & \begin{tabular}{|c} 
individ \\
uen
\end{tabular} \\
\hline A004 & Dodaars & $=$ & $=$ & 80 \\
\hline A005 & Fuut & $=$ & $=$ & 370 \\
\hline A007 & Kuifduiker & $=$ & $=$ & 8 \\
\hline A017 & Aalscholver & $=$ & $=$ & 360 \\
\hline A026 & Kleine zilverreiger & $=$ & $=$ & 20 \\
\hline A034 & Lepelaar & $=$ & $=$ & 30 \\
\hline A037 & Kleine zwaan & $=$ & $=$ & \\
\hline A043 & Grauwe gans & $=$ & $=$ & 2300 \\
\hline A045 & Brandgans & $=$ & $=$ & 3100 \\
\hline A046 & Rotgans & $=$ & $=$ & 6300 \\
\hline A048 & Bergeend & $=$ & $=$ & 2900 \\
\hline A050 & Smient & $=$ & $=$ & 12000 \\
\hline A051 & Krakeend & $=$ & $=$ & 130 \\
\hline A052 & Wintertaling & $=$ & $=$ & 1000 \\
\hline A053 & Wilde eend & $=$ & $=$ & 5500 \\
\hline A054 & Pijlstaart & $=$ & $=$ & 730 \\
\hline A056 & Slobeend & $=$ & $=$ & 940 \\
\hline A067 & Brilduiker & $=$ & $=$ & 680 \\
\hline A069 & Middelste zaagbek & $=$ & $=$ & 350 \\
\hline A103 & Slechtvalk & $=$ & $=$ & 10 \\
\hline A125 & Meerkoet & $=$ & $=$ & 1100 \\
\hline A130 & Scholekster & $=$ & $=$ & 24000 \\
\hline
\end{tabular}




\begin{tabular}{|c|c|c|c|c|}
\hline & & \multicolumn{3}{|c|}{ Gebiedsdoelstelling } \\
\hline & & 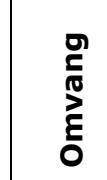 & $\begin{array}{l}\frac{ \pm}{d} \\
\frac{ \pm}{\pi} \\
\frac{\pi}{3} \\
\underline{x}\end{array}$ & $\begin{array}{l}\frac{0}{+0} \\
\frac{\pi}{3} \\
0 \\
0 \\
0\end{array}$ \\
\hline A132 & Kluut & $=$ & $=$ & 510 \\
\hline A137 & Bontbekplevier & $=$ & $=$ & 280 \\
\hline A138 & Strandplevier & $=$ & $=$ & 50 \\
\hline$A 140$ & Goudplevier & $=$ & $=$ & 2000 \\
\hline A141 & Zilverplevier & $=$ & $=$ & 4400 \\
\hline A143 & Kanoetstrandloper & $=$ & $=$ & 7700 \\
\hline$A 144$ & Drieteenstrandloper & $=$ & $=$ & 260 \\
\hline A149 & Bonte strandloper & $=$ & $=$ & 14100 \\
\hline A157 & Rosse grutto & $=$ & $=$ & 4200 \\
\hline A160 & Wulp & $=$ & $=$ & 6400 \\
\hline A161 & Zwarte ruiter & $=$ & $=$ & 310 \\
\hline A162 & Tureluur & $=$ & $=$ & 1600 \\
\hline A164 & Groenpootruiter & $=$ & $=$ & 150 \\
\hline A169 & Steenloper & $=$ & $=$ & 580 \\
\hline
\end{tabular}

\subsection{Relevante beschermde natuurwaarden}

Deze paragraaf beschrijft de relevante natuurwaarden met betrekking tot de kweekactiviteiten voor off-bottom oesterteelt in de Oosterschelde. De activiteiten met betrekking tot de off-bottom oesterteelt in de Oosterschelde vinden plaats in het natte deel van het Natura 2000-gebied. De terrestrische habitat typen (H1310A, H1320, H1330A, H1330B en H7140B) worden op voorhand niet beïnvloed door de kweekactiviteiten en zijn daarmee niet relevant voor deze PB. Dit geldt ook voor de Noordse Woelmuis (H1310), die voor kan komen op slikken, maar deze zijn ver verwijderd van de kweek locatie (Fig. 10).

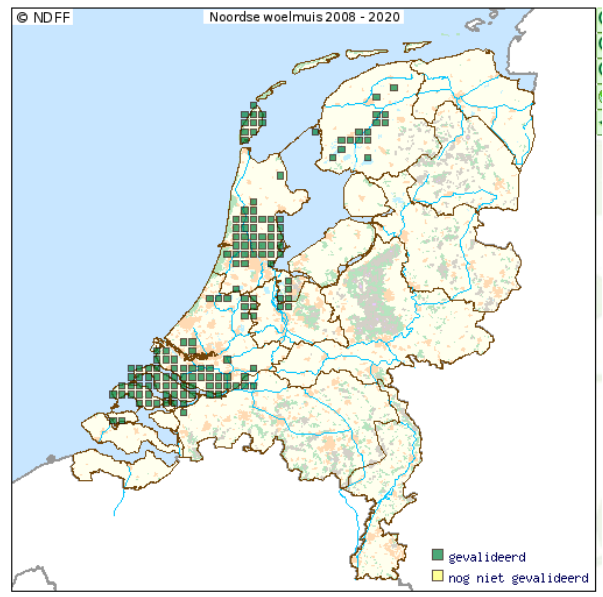

Figuur 10. Verspreiding van de Noordse woelmuis in Nederland (www.telmee.nl).

Het habitattype is $\mathrm{H} 1160$ (Grote baaien), zijnde het habitattype waarbinnen de oesterteelt plaatsvindt, is wel relevant en dus onderwerp van deze PB. Het habitattype is in de Oosterschelde tot stand gekomen door de aanleg van dammen die de zoetwateraanvoer van het oorspronkelijke estuarium beperken. De soortensamenstelling van de Oosterschelde is uniek en verschilt van alle andere grote baaien in Europa. 
De Gewone zeehond (H1365) verkeert landelijk in een gunstige staat van instandhouding. Voor de Deltawateren geldt een regiodoelstelling van minstens 200 dieren. Deze doelstelling wordt, mede dankzij immigratie vanuit andere gebieden, met ca. 577 dieren in 2013 ruimschoots gehaald (Wijsman \& Goudswaard, 2015). Een tweede doelstelling is dat de populatie in de Delta zelfstandig levensvatbaar is. In Reed et al. (2003) is een overzicht gegeven van de minimale levensvatbare populatieomvang van een groot aantal vertebraten. De Gewone zeehond komt in dit overzicht niet voor, maar wel is de Grijze zeehond opgenomen. Van deze soort is de minimale levensvatbare populatieomvang 2344 individuen. Het is dus niet te verwachten dat het aantal van 577 Gewone zeehonden in 2013 in de Delta als zelfstandige populatie levensvatbaar is. De Gewone zeehond populatie in de Delta blijft dus afhankelijk van de migratie, voornamelijk uit het Waddengebied.

Tenslotte zijn er diverse broedvogels en niet-broedvogels die de slikken en platen gebruiken om te foerageren en als hoogwatervluchtplaats of die duikend hun voedsel verzamelen in diepere delen van de Oosterschelde. 


\section{$5 \quad$ Effectenanalyse}

In dit hoofdstuk worden de te verwachten effecten van de oesterkweekactiviteiten op de volgende natuurwaarden besproken: Grote baaien, Gewone zeehonden, broed- en niet-broedvogels. Voor ieder van deze natuurwaarden is specifiek gekeken naar de potentiële effecten als gevolg van de kweekactiviteiten.

\subsection{Verstoring van beschermde soorten}

Kweekactiviteiten kunnen vogels en zeehonden verstoren. De activiteiten in het kader van dit project vinden echter niet iedere dag plaats en zijn van korte duur (zie 2.2.4). Er wordt geen geluidsapparatuur, anders dan ten behoeve van communicatiedoeleinden, gebruikt. Anderzijds kunnen kweeksystemen ook positieve effecten op beschermde soorten hebben, omdat ze dienen als kunstmatige rustplaats (Kamermans et al., 2014), beschutting leveren of mogelijk ook voedsel in de vorm van vissen en macroalgen aantrekken. Verstoring van vogels door gebruik van verlichting is bij oesterteelt niet aan de orde omdat uitsluitend bij daglicht wordt gewerkt.

Visuele verstoring betreft verstoring door de aanwezigheid en/of beweging van mensen dan wel voorwerpen die niet thuishoren in het natuurlijke systeem. Visuele verstoring leidt vooral tot vluchtgedrag van dieren. De soort reageert bijvoorbeeld op beweging omdat een potentiële vijand wordt verwacht. Andersom kan optische verstoring juist ook het uitzicht van soorten beperken waardoor zij potentiële vijanden niet zien naderen.

De werkzaamheden ten behoeve van het kweken van oesters kunnen door het daarbij geproduceerde geluid en de bewegingen leiden tot een tijdelijke verstoring van de in het gebied aanwezige fauna. Dat geldt ook voor het geluid (incl. trillingen) en de beweging van het schip waarmee het systeem wordt geplaatst en onderhouden. Het geluid door de oesterkweek en de bijbehorende scheepvaart bestaat uit geluid boven water en onder water. Geluid boven water kan tot verstoring van vogels leiden. Onderwatergeluid kan leiden tot verstoring van vissen, zeezoogdieren en evt. bereikbaarheid van voedselsoorten van duikende vogels.. Het gaat uitsluitend om verstoring van tijdelijke aard, aangezien de activiteit van korte duur is en de verstoring ophoudt zodra de activiteit is voltooid. Daarnaast is de motor van het schip uit als er gewerkt wordt aan de off-bottom kweekopstellingen. Daarom is de verwachting dat er minimaal sprake is van extra verstoring door de voorgestelde off-bottom kweekactiviteiten. Ook de populatiedynamiek van beschermde soorten wordt niet verstoord.

De plaatsing van de opstellingen vindt plaats in het sub en laag-litoraal. De opstellingen bewegen niet en zijn in het laag-litoraal alleen te zien met laag water. Activiteiten bij laag water in Broek en Yerseksche Oesterbank waarbij mensen aanwezig zijn en het grootste risico vormen voor het storen van vogels zijn beperkt en kortdurend. Er wordt gemiddeld 2 maal per maand over een periode van 24 uur gewerkt. Het monitoren van vogels is onderdeel van het monitoringprogramma (zie onderzoeksen monitoringplan in bijlage 2).

\subsection{Verontreiniging}

Bij het kweken van oesters en het oogsten ervan komen geen chemische stoffen in het water. De oesterteelt vindt plaats in kunststof zakken. De kooien zijn gemaakt van betonijzer en de lijnen voor kooien zijn van nylon en bevestigd aan PE drijvers. Door stormen gepaard met grote golfkracht raken deze materialen of delen daarvan soms los en komen dan in het ecosysteem terecht. Ook bestaat de kans dat door werkzaamheden, als uitdunnen en oogsten of door verwering, kleine partikels (microplastics) in het ecosysteem terecht komen. Daarbij is het mogelijk dat deze deeltjes vervolgens opgenomen worden door filtrerende organismen (b.v. oesters of mosselen) of door sediment etende 
organismen (b.v. wormen). Recent onderzoek laat zien dat mosselen microplastics uit het water kunnen filtreren (Wegner et al., 2012). De zakken worden doorgaans na 5 jaar vervangen. Er wordt geen afval achter gelaten. De te gebruiken installaties zijn deugdelijk van constructie. Er zijn geen aanwijzingen dat slijtage van de materialen effecten zullen hebben op het ecosysteem. Indien overmatige slijtage van de kunststof wordt geconstateerd, worden deze binnen twee weken vervangen. Op basis van de beschikbare kennis en mitigerende maatregelen worden geen als significante nadelige effecten verwacht op de instandhoudingsdoelen.

De geplande kweekactiviteiten gaan gepaard met scheepsbewegingen van en naar het gebied. Op de kweeklocatie zal het schip stil liggen om de werkzaamheden aan de zakken te kunnen uitvoeren. Het monitoren van scheepsbewegingen is onderdeel van het monitoringprogramma (zie onderzoeks- en monitoringplan in bijlage 2). De Aerius calculator (https://calculator.aerius.nl/calculator/) berekent de stikstofuitstoot voor verschillende menselijk activiteiten. Een Aerius berekening is uitgevoerd voor de categorie koelschepen en vissersschepen GT: 100-1599. GT staat voor gross tonnage. Dit is een nonlineaire maat voor het interne volume van een schip. De schepen die de kwekers gaan gebruiken zullen over het algemeen kleiner zijn, maar die optie was niet beschikbaar in de Aerius calculator. Er is uitgegaan van 3 kwekers die elk 10 keer per 2 weken (26 weken in het jaar) nodig hebben voor het uitvoeren van onderhoud aan de tafels, kooien en longlines. De verwachting is dat in één dag bij hoogwater werk kan worden uitgevoerd bij een sublitorale locatie, en dat diezelfde dag bij laagwater een litoraal locatie bezocht kan worden. Hierbij wordt gerekend twee routes: 1) Haven Yerseke Lodijkse Gat - Broek - Haven Yerseke; en 2) Haven Yerseke - Yerseksche Oesterbank - Koeiegat Haven Yerseke. Beide routes zullen een verwachte 390 scheepsbewegingen per jaar opleveren, met een totaal van 780 scheepsbewegingen. Route 1 resulteert in een geschatte stikstof (NOx) emissie van $8185.9 \mathrm{~kg} / \mathrm{jaar}$ en route 2 voor $9475.7 \mathrm{~kg} / \mathrm{jaar}$ met een totaal van $17661.3 \mathrm{~kg} / \mathrm{jaar}$ (Bijlage 3). De verwachte stikstof depositie ligt per gebied afzonderlijk onder de standaard drempel van 1 $\mathrm{mol} / \mathrm{ha} / \mathrm{jaar}$. Dit leidt niet tot effecten op de beschermde natuurwaarden, waardoor er geen vergunningsplicht met betrekking tot stikstofemissie is. Voor de gebieden Brabantse Wal en KrammerVolkerak is de grenswaarde verlaagd naar $0,05 \mathrm{~mol} / \mathrm{ha} / \mathrm{jr}$ en is er dus wel sprake van een vergunningplicht m.b.t. stikstof.

\subsection{Verandering dynamiek substraat}

Het aangewezen habitattype in de Oosterschelde is H1160 Grote baaien. Typische soorten van dit habitat type kunnen beïnvloed worden door de voorgenomen activiteit. Schelpdieren filtreren organische en anorganische deeltjes uit het water. Slechts een deel van het gefilterde materiaal wordt verteerd in het maag-darm kanaal waarbij de restproducten worden uitgescheiden als faeces. De rest gaat niet door het maag-darmkanaal, en wordt daarvoor reeds verwijderd als pseudofaeces. Pseudofaeces en faeces bezitten hoge gehaltes aan organische stof. Ze bezinken richting bodem (depositie) en worden tijdens dit proces door de waterstroming meegevoerd en verspreid, vaak ook weer opgewerveld en verder gevoerd tot ze opnieuw bezinken (de Mesel et al., 2008). Het organisch rijker worden van de bodem als gevolg van depositie kan leiden tot verandering van de omstandigheden voor soorten die in arme omstandigheden voorkomen. Andere soorten kunnen juist baat hebben bij depositie en verrijkte omstandigheden. Bepalende factoren daarbij zijn de mate waarin golven en stroming organisch materiaal verspreiden en de kwetsbaarheid van het natuurlijk bodemleven.

De de teelt van oesters is gepland op de vrije grond en op oesterpercelen. Op de vrije grond heeft nog niet eerder oesterteelt plaatsgevonden. Vanwege de diepte is de verwachting dat er geen significante effecten van veranderingen in stroming rond de lijnen met kooien zal optreden. Daarom wordt geen verandering in dynamiek van het substraat als gevolg van bezinken van pseudofaeces en faeces verwacht. Het slibgehalte in de bodem is onderdeel van het monitoringprogramma (zie onderzoeks- en monitoringplan in bijlage 2). 


\subsection{Verandering soortensamenstelling}

De kooien en zakken worden in het sublitoraal en laag-litoraal van de Oosterschelde geplaatst. Doordat er geen verhoogde sedimentatie wordt verwacht in het Lodijkse Gat zal er geen effect zijn op de kwaliteit van het bodemhabitat. Doordat de bodem op de locaties Koeiegat, Broek en Yerseksche Oesterbank eerder in gebruik was voor bodemcultuur van oesters, zal er geen effect zijn op de kwaliteit van het bodemhabitat.

\subsection{Verlies oppervlakte}

Oesterkweek in zakken kan effect hebben op de kwaliteit van het habitattype H1160 door beïnvloeding van natuurlijke processen (stromingspatronen, sedimentatie en erosie). Doordat er voor de lijnen ankers in de bodem worden aangebracht waaronder geen bodemleven kan plaatsvinden is er feitelijk sprake van verlies van een habitatoppervlakte van enkele vierkante meters. Ten opzichte van de oppervlakte van de Oosterschelde is dit met zekerheid niet relevant. Indien ankers worden verwijderd, zal ter plaatse met zekerheid herstel van de bodem en het bodemleven optreden. Het effect is derhalve niet onomkeerbaar. Door de diepte van de locatie zullen de kooien met zakken geen effect hebben op de lichtinval op de bodem. De tafels geplaatst in het laag-litoraal kunnen door schaduwwerking de lichtinval op de bodem beperken, waarmee het plantaardige bodemleven ter plaatse nadelig kan worden beïnvloed. Hier is nog erg weinig over bekend; bepaling van de concentratie aan bodemdiatomeeën is onderdeel van het monitoringprogramma (zie onderzoeks- en monitoringplan in bijlage 2).

De ligging van de zoutgradiënt, uitgedrukt als de verhouding zout en brak gebied binnen habitattype 1160, wijzigt niet. De water(bodem)kwaliteit, uitgedrukt als de concentraties nutriënten en milieuvreemde stoffen, wijzigt eveneens niet.

De voorgenomen activiteit heeft geen significant effect op het ontstaan van meerjarige stabiele mosselbanken, aangezien er niet op de bodem wordt gevist.

Oesters filtreren organische en anorganische deeltjes uit het water. Deze filtratiedruk kan de draagkracht van de voedselketen beïnvloeden (zie Kamermans et al., 2014; Smaal et al., 2013). Effecten op de draagkracht en op de instandhoudingsdoelen worden niet verwacht vanwege de volgende redenen:

- Het totale areaal aan oesterbanken op droogvallende platen in de Oosterschelde is in het voorjaar van 2014, 2015 en 2016 door IMARES geschat op respectievelijk 558, 519 en 513 hectare. Daarmee lijkt het areaal licht af te nemen (van den Ende et al., 2014, zie ook van den Ende et al.,2016 en van de Ende et al. in prep.). De afname kan verklaard worden doordat het areaal aan oesterbanken in de Kom (54, 8, 9 ha in 2014, 2015, 2016 respectievelijk) van de Oosterschelde is afgenomen door het wegvissen van wilde oesters, en sterfte door het oesterherpesvirus en oesterboorders. In de rest van de Oosterschelde is het areaal behoorlijk stabiel (Monding: 164, 151, 151 hectare; Midden: 198, 210, 195 hectare; Noordtak: 142, 151, 159 hectare; in 2014, 2015 en 2016 respectievelijk) (van den Ende et al., 2014, 2015, 2016 en van de Ende et al. in prep.).

- De draagkrachtberekeningen voor de Oosterschelde gaan uit van een worst-case scenariomet een biomassa waarbij de percelen volledig benut worden. Dit is al jaren niet het geval. Het project is tijdelijk en de verwachting is dat bovenstaande situatie niet in een paar jaar zal veranderen.

- In het project gaat het om een kleine hoeveelheid oesters op oesterpercelen en op een plaats waar in de directe omgeving oesters voorkomen; op het totaal van $9 \mathrm{mln} \mathrm{kg}$ bedraagt de stock van 400.000 $\mathrm{kg}$, overeenkomende met ca. $4.5 \%$.

- De verwachting is dat off-bottom oesters iets sneller groeien, daarnaast bevatten de installaties meer oesters dan op hetzelfde oppervlak op de bodem gekweekt zouden worden. Dit vergroot de efficiëntie van de oesterkweek. Dat is een van de doelstellingen van het Plan van Aanpak 'Oestermaatregelen' 2016 - 2018 (NOV, 2016).

- Een eventueel effect op draagkracht door gebruik van hatchery oesters zal worden gemitigeerd door het wegvissen van wilde oesters die aanwezig zijn op niet in gebruik zijnde kweekpercelen. Hierbij kan zoveel biomassa worden weggevist als maximaal aanwezig zal zijn bij oogst. 
Op grond van het bovenstaande komen wij tot de conclusie dat er geen effect is op de draagkracht. In navolging van de meerjarige productie- en effectmetingen aan mosselzaadinvanginstallaties (MZI's) (project 2009-2013; Kamermans et al., 2013), is van 2015-2017 een monitoringsprogramma ('Draagkracht MZI') uitgevoerd in opdracht van het ministerie van EZ (Kamermans \& van Asch, 2018). De centrale vraag bij dit onderzoek was: Heeft de opschaling van MZI's effect op de draagkracht voor schelpdieren in de Waddenzee en Oosterschelde? Monitoring is van belang om mogelijke effecten van de opschaling zichtbaar te maken en te kunnen evalueren. De indicatoren voor een veranderende draagkracht die werden onderzocht, zijn het vleesgehalte van aangevoerde mosselen en de groei van kokkels zoals die blijkt uit de jaarlijkse surveys. Het gebruik van de draagkrachtindicatoren werkt als volgt: een afname van het vleesgehalte van mosselen en een afname van de groei van kokkels wijzen op een afname van de draagkracht voor schelpdieren. Uit Smaal et al. (2013) blijkt dat vleesgehalte een goede indicatie van draagkracht is. Met dit onderzoek is het mogelijk een vinger aan de pols te houden. Analyse van de data vanaf 1992 tot en met 2016 laat zien dat het vleesgehalte van mosselen en de groei van kokkels in de Oosterschelde fluctueert in ruimte en tijd, maar geen trend in de tijd vertoont (Kamermans \& van Asch, 2018).

Effecten op de kwaliteit van habitattype 1160 (grote ondiepe kreken en baaien) zijn niet te verwachten, omdat door de voorgenomen activiteit het oppervlak of de kwaliteit van het habitattype niet wordt aangetast. Tevens is geen negatief effect op vissen is te verwachten, daar de kweek geheel in zakken plaatsvindt.

\subsection{Vogels}

De oesters worden gekweekt in zakken in kooien en op tafels in het sublitoraal en laag-litoraal van de Oosterschelde. In de omgeving van de installaties wordt door diverse vogelsoorten gefoerageerd in het water en op de droogvallende platen. Voor de vogels die op het open water verblijven (Tabel 5) zal de verstoring minimaal zijn, aangezien zij ruime mogelijkheden hebben om bij verstoring in de omgeving een alternatieve verblijfplaats te vinden en de activiteit zeer lokaal en tijdelijk is. Rond extreem laagwater bij Broek en Yeresksche Oesterbank zullen de installaties zich boven de laagwaterlijn bevinden en zullen vogels die op droogvallende platen foerageren zich binnen de vluchtafstand bevinden terwijl men aan het werk is. Daarom wordt op dagen met extreem laagwater niet gewerkt. Rijkswaterstaat verzameld regelmatig vogeltellinggegevens van bepaalde locaties in de Oosterschelde. Met deze gegevens is het mogelijk om de aanwezigheid, hoeveelheid en type vogelsoorten die voorkomen in verschillende gebieden. Voor de twee laag-litorale locaties zijn de vogelgegevens van het dichtstbij vogeltelling telgebied (Broek: OS532 en Yerseksche Oesterbank: OS630) (zie Fig. 3) geanalyseerd. Van de beschermde op platen foeragerende vogelsoorten komen 10 voor bij Broek (Bijlage 4) en acht bij de Yerseksche Oesterbank (Bijlage 5) en tabel 6.

Voor de vogelsoorten geldt een behoudsdoelstelling voor omvang kwaliteit (Tabel 1). Echter, omdat er op deze locaties alleen wordt gewerkt als het gebied onder water staat, is de verwachte verstoring op deze foeragerende vogelsoorten minimaal en kortdurend. De drijvers en boven het water uitstekende installaties kunnen dienen als rustplaats voor de vogels. Er zijn geen als significant te beoordelen effecten op vogels en de omvang van hun leefgebied te verwachten. Het monitoren van vogels is onderdeel van het monitoringprogramma (zie onderzoeks- en monitoringplan in bijlage 2).

Tabel 5. Verstoringsgevoeligheid van vogels die in het water foerageren in het studiegebied OS532 (Broek) en OS630 (Yerseksche Oesterbank). De aangegeven afstanden zijn gebaseerd op Krijgsveld et al. (2008).

\begin{tabular}{|l|c|c|c|c|}
\hline soort & Aanwezig in Broek & $\begin{array}{c}\text { Aanwezig in Yerseksche } \\
\text { Oesterbank }\end{array}$ & vluchtafstand $(\mathrm{m})$ & alert afstand $(\mathrm{m})$ \\
\hline A004 Dodaars & $\mathrm{X}$ & $\mathrm{X}$ & 200 & 400 \\
\hline
\end{tabular}




\begin{tabular}{|l|c|c|c|c|}
\hline A005 Fuut & $\mathrm{X}$ & $\mathrm{X}$ & 200 & 450 \\
\hline A017 Aalscholver & $\mathrm{X}$ & $\mathrm{X}$ & 75 & 150 \\
\hline A067 Brilduiker & $\mathrm{X}$ & $\mathrm{X}$ & 250 & 575 \\
\hline A069 Middelste Zaagbek & $\mathrm{X}$ & $\mathrm{X}$ & 250 & 575 \\
\hline A125 Meerkoet & $\mathrm{X}$ & $\mathrm{X}$ & 100 & 200 \\
\hline A050 Smient & $\mathrm{X}$ & $\mathrm{X}$ & 250 & 575 \\
\hline A051 Krakeend & $\mathrm{X}$ & & 250 & 575 \\
\hline A052 Wintertaling & $\mathrm{X}$ & $\mathrm{X}$ & 250 & 575 \\
\hline A053 Wilde Eend & $\mathrm{X}$ & $\mathrm{X}$ & 250 & 575 \\
\hline A054 Pijlstaart & $\mathrm{X}$ & & 250 & 575 \\
\hline A056 Slobeend & $\mathrm{X}$ & & 250 & 575 \\
\hline
\end{tabular}

Tabel 6. Verstoringsgevoeligheid van beschermde vogelsoorten die op droogvallende platen foerageren in het voorgestelde laag-litorale studiegebieden. De aangegeven afstanden zijn gebaseerd op Krijgsveld et al. (2008). Aanwezigheid gebaseerd op Vogeltellingen telgebied RWS OS532 (Broek) en OS630 (Yerseksche Oesterbank) (zie Fig. 3) in de periode 2013 t/m 2016 (data servicedesk Rijkswaterstaat).

\begin{tabular}{|l|c|c|c|c|}
\hline \multicolumn{1}{|c|}{ soort } & $\begin{array}{c}\text { Aanwezig in } \\
\text { Broek }\end{array}$ & $\begin{array}{c}\text { Aanwezig in } \\
\text { Yerseksche } \\
\text { Oesterbank }\end{array}$ & $\begin{array}{c}\text { vluchtafstand } \\
(\mathrm{m})\end{array}$ & $\begin{array}{c}\text { alert afstand } \\
(\mathrm{m})\end{array}$ \\
\hline A130 Scholekster & $\mathrm{x}$ & $\mathrm{x}$ & 100 & 175 \\
\hline A137 Bontbekplevier & $\mathrm{x}$ & $\mathrm{x}$ & 100 & 175 \\
\hline A141 Zilverplevier & $\mathrm{x}$ & $\mathrm{x}$ & 100 & 175 \\
\hline A143 Kanoetstrandloper & $\mathrm{x}$ & & 125 & 300 \\
\hline A144 Drieteenstrandloper & $\mathrm{x}$ & & 125 & 300 \\
\hline A149 Bonte strandloper & $\mathrm{x}$ & $\mathrm{x}$ & 125 & 300 \\
\hline A157 Rosse grutto & $\mathrm{x}$ & $\mathrm{x}$ & 125 & 300 \\
\hline A160 Wulp & $\mathrm{x}$ & $\mathrm{x}$ & 125 & 300 \\
\hline A162 Tureluur & $\mathrm{x}$ & $\mathrm{x}$ & 125 & 300 \\
\hline A169 Steenloper & $\mathrm{x}$ & $\mathrm{x}$ & 125 & 300 \\
\hline
\end{tabular}

Voor alle soorten geldt een behoudsdoelstelling voor omvang en kwaliteit (tabel 2 in paragraaf 4.1).

Voor vogels in hun broedgebieden geldt een verstoringafstand van $500 \mathrm{~m}$ (Jongbloed et al., 2009). Broedgebieden van de soorten broedvogels uit Tabel 1 (Kluut, Bontbekplevier, Strandplevier) komen niet voor binnen $500 \mathrm{~m}$ van de werkingssfeer van de oesterkweeksystemen

(http://www.synbiosys.alterra.nl/natura2000/gebiedendatabase.aspx?subj=profielen). Daarom worden er geen effecten verwacht op de beschermde broedvogelsoorten.

Verstoring van vogels op hoogwatervluchtplaatsen wordt niet verwacht, omdat de werkzaamheden in het laag-litoraal plaats vinden tijdens laagwater.

Gelet op de wijze van kweken, in gesloten zakken met kleine openingen, kunnen vogelsoorten die foerageren of duikend hun voedsel bemachtigen niet bij de oesters. Overigens vormen voor geen van de doelsoorten oesters (preferent) voedsel. Gezien de aard van de activiteit en het feit dat oesters geen belangrijke voedselbron vormen, is niet te verwachten dat het voedselaanbod voor deze soorten door de oesterkweek zal afnemen.

De vormgeving van de zakken is zodanig dat vogelsoorten welke al duikend hun voedsel bemachtigen er niet in verstrikt kunnen raken. Tijdens elk bezoek worden de systemen gecontroleerd op vogelslachtoffers.

Er zijn geen als significant te beoordelen effecten op vogels en de omvang van hun leefgebied te verwachten; het monitoren van vogels is onderdeel van het monitoringprogramma (zie onderzoeksen monitoringplan in bijlage 2). 


\subsection{Habitatsoorten}

De Oosterschelde is voor een tweetal habitatsoorten aangewezen: de Gewone zeehond (H1365) en de Noordse woelmuis (H1340). De Noordse woelmuis komt niet voor in het gebied waar het project plaatsvindt (Fig. 7).

De Oosterschelde heeft voor zeehonden een functie als voedsel- en verblijfgebied. Voor het vervullen van deze functies zijn platen met aanliggende diepe geulen van belang. Het werpen van jongen vindt plaats op rustig gelegen platen. Zeehondenligplaatsen bevinden zich in het midden en het westen van de Oosterschelde. In de buurt van de kweeklocatie zijn geen opgroei- en rustgebieden van de zeehond gesitueerd, waardoor geen significante effecten op de populatie Gewone zeehonden te verwachten zijn (Wijsman \& Goudswaard, 2015). 


\section{$6 \quad$ Mitigerende maatregelen}

- Er wordt niet gewerkt op dagen met zulk laag water dat de laag-litorale locaties droogvallen (zie 2.2.4)

- De te gebruiken installaties zijn deugdelijk van constructie (zie 2.2.1).

- Indien overmatige slijtage van de kunststof wordt geconstateerd, worden deze binnen een maand vervangen (zie 2.2.1).

- Er wordt geen geluidsapparatuur anders dan ten behoeve van communicatiedoeleinden gebruikt (zie 5.1).

- Er wordt geen afval achter gelaten (zie 5.2).

- De werkzaamheden worden bij daglicht uitgevoerd (zie 5.1).

- Tijdens elk bezoek worden de systemen gecontroleerd op vogelslachtoffers (zie 5.6).

- Een eventueel effect op draagkracht door gebruik van hatchery oesters zal worden gemitigeerd door het wegvissen van wilde oesters. Hierbij kan zoveel biomassa worden weggevist als maximaal aanwezig zal zijn bij oogst (zie 5.5). 


\section{$7 \quad$ Cumulatieve effecten}

\section{Draagkracht}

De productie van oesters uit de hatchery vergroot het bestand aan schelpdieren in de Oosterschelde. Dit kan via een extra beslag op het aanwezige voedsel (microalgen) een effect hebben op de instandhoudingsdoelen voor de beschermde natuurwaarden en kenmerken. Boven een bepaalde graasdruk door schelpdieren kan de beschikbaarheid van microalgen minder worden. Dit kan doorwerken in een verminderde groei van de schelpdieren die op hun beurt weer als voedsel dienen voor bepaalde vogelsoorten. Het effect wordt bepaald door de mate van waterverversing, het niveau van de algenproductie en de filtratiedruk vanuit de natuur en schelpdierkweek. Er is geen vaste draagkrachtdrempel aan te wijzen, omdat de beschikbaarheid van algen van vele factoren tegelijkertijd afhankelijk is (de watertemperatuur, de hoeveelheid licht in het water, de hoeveelheid voedingsstoffen voor de algen, de aanwezigheid van andere soorten die algen eten (schelpdieren, zoöplankton, etc.). Wel kan worden aangegeven in hoeverre de voorgenomen activiteit een substantiële bijdrage kan leveren in het vergroten van de hoeveelheid schelpdieren die algen eten, of in hoeverre de vergroting wegvalt in de ruis rondom de voedselbeschikbaarheid die wordt veroorzaakt door de andere bovengenoemde factoren. Een effect op de draagkracht (voedselbeschikbaarheid) kan een doorwerking hebben op de beschermde soorten wanneer hierdoor de groei van natuurlijke schelpdierbestanden wordt beïnvloed (schelpdieretende vogels) ofwel de beschikbaarheid van microalgen via schakels als zoöplankton effecten heeft via de voedselketen (overige soorten). Voor de N2000-doelen gaat het met name om schelpdieretende vogels. Deze foerageren op droogvallende platen en eten voornamelijk kokkels. De toename van het schelpdierbestand zal ca. 4,5\% bedragen ten opzichte van het totaal. In opdracht van het ministerie van Economische Zaken is in het kader van het mosselconvenant de draagkracht van de Oosterschelde voor schelpdieren gemonitord (Kamermans $\&$ van Asch, 2018). Met dit onderzoek is het mogelijk een vinger aan de pols te houden. De methode is operationeel (project gefinancierd door EZ) en gebaseerd op studies die zijn uitgevoerd en gepubliceerd gedurende het project Meerjarige effect- en productiemetingen aan MZI's in de Westelijke Waddenzee, Oosterschelde en Voordelta (ook gefinancierd door EZ, Kamermans et al., 2014). De laatste jaren zijn er geen aanwijzingen dat de draagkracht van de Oosterschelde afneemt.

\section{Verstoring vogels}

Er wordt geen effect verwacht op het leefgebied van op het water levende vogels door de geplande kweekactiviteiten en vaarbewegingen. Een cumulatief effect door de aanwezigheid van mosselzaadinvanginstallaties (MZI's) en mosselhangcultures (MHCs) in de Oosterschelde wordt dan ook niet verwacht. De geplande kweekactiviteiten gaan gepaard met scheepsbewegingen van en naar de proeflocaties. De proeflocaties bevinden zich in de Kom van de Oosterschelde. Dit is een gebied waar dagelijks vaarbewegingen plaats vinden in verband met werk op de percelen.

\section{Zandhonger}

De zandhonger van de Oosterschelde wordt niet vergroot door de oesterkweekinstallaties. De verandering in slibgehalte zal niet significant zijn. 


\section{Conclusie}

Off-bottom oesterkweek op de locaties Lodijkse Gat, Koeiegat, Broek en Yerseksche Oesterbank in het sublitoraal en laag litoraal van de Oosterschelde is geanalyseerd wat betreft de effecten op de Natura 2000-instandhoudingsdoelstellingen van habitats en soorten. Ook is ingegaan op mitigerende maatregelen en cumulatieve effecten.

De conclusie is dat er op basis van de beschikbare informatie die in voorliggende Passende Beoordeling is samengevat geen significante negatieve effecten zijn van oesterkweek activiteiten op locaties Lodijkse Gat, Koeiegat, Broek, en Yerseksche Oesterbank in het sublitoraal en laag litoraal van de Oosterschelde op de Natura 2000-instandhoudingdoelstellingen van habitats en soorten en aan de orde zijnde verbeteropgaven voor deze gebieden. 


\section{Kwaliteitsborging}

Wageningen Marine Research beschikt over een ISO 9001:2008 gecertificeerd kwaliteitsmanagementsysteem (certificaatnummer: 187378-2015-AQ-NLD-RvA). Dit certificaat is geldig tot 15 december 2018. De organisatie is gecertificeerd sinds 27 februari 2001. De certificering is uitgevoerd door DNV Certification B.V..

Het chemisch laboratorium te IJmuiden beschikt over een NEN-EN-ISO/IEC 17025:2005 accreditatie voor testlaboratoria met nummer L097. Deze accreditatie is geldig tot 1 april 2021 en is voor het eerst verleend op 27 maart 1997; deze accreditatie is verleend door de Raad voor Accreditatie. Het chemisch laboratorium heeft hierdoor aangetoond in staat te zijn op technisch bekwame wijze valide resultaten te leveren en te werken volgens de ISO17025 norm. De scope (L097) met de geaccrediteerde analysemethoden is te vinden op de website van de Raad voor Accreditatie (www.rva.nl).

Op grond van deze accreditatie is het kwaliteitskenmerk $\mathrm{Q}$ toegekend aan de resultaten van die componenten die op de scope staan vermeld, mits aan alle kwaliteitseisen is voldaan. Het kwaliteitskenmerk Q staat vermeld in de tabellen met de onderzoeksresultaten. Indien het kwaliteitskenmerk $Q$ niet staat vermeld is de reden hiervan vermeld.

De kwaliteit van de analysemethoden wordt op verschillende manieren gewaarborgd. De juistheid van de analysemethoden wordt regelmatig getoetst door deelname aan ringonderzoeken waaronder die georganiseerd door QUASIMEME. Indien geen ringonderzoek voorhanden is, wordt een tweede lijnscontrole uitgevoerd. Tevens wordt bij iedere meetserie een eerstelijnscontrole uitgevoerd. Naast de lijnscontroles wordende volgende algemene kwaliteitscontroles uitgevoerd:

- Blanco onderzoek.

- Terugvinding (recovery).

- Interne standaard voor borging opwerkmethode.

- Injectie standard.

- Gevoeligheid.

Bovenstaande controles staan beschreven in Wageningen Marine Research werkvoorschrift ISW 2.10.2.105.

Indien gewenst kunnen gegevens met betrekking tot de prestatiekenmerken van de analysemethoden bij het chemisch laboratorium worden opgevraagd.

Indien sprake is van onbeheerste kwaliteit worden passende maatregelen genomen. 


\section{Literatuur}

Boudry, P. (2008). Review on Breeding and Reproduction of European aquaculture species Pacific oyster (Crassostrea gigas). Aqua Breeding report.

Dundon, W.G., I. Arzul, E. Omnes, M. Robert, C. Magnabosco, M. Zambon \& G. Arcangeli (2011). 'Detection of Type 1 Ostreid Herpes variant (OsHV-1 $\mu$ var) with no associated mortality in Frenchorigin Pacific cupped oyster Crassostrea gigas farmed in Italy'. In: Aquaculture, 314(1), 49-52.

Faasse, M. A. \& M. Ligthart (2009). American (Urosalpinx cinerea) and Japanese oyster drill (Ocinebrellus inornatus) (Gastropoda: Muricidae) flourish near shellfish culture plots in The Netherlands. Aquatic Invasions 4: 321-326.

Gagnaire B., P. Soletchnik, P. Madec, P. Geairon, O. Le Moine \& T. Renault (2006). Diploid and triploid Pacific oysters, Crassostrea gigas (Thunberg), reared at two heights above sediment in MarennesOleron Basin, France: Difference in mortality, sexual maturation and hemocyte parameters. Aquaculture 254: 606-616.

Garnier-Gere, P.H., Naciri-Graven, Y., Bougrier, S., Magoulas, A., Heral, M., Kotoulas, G., Hawkins, A., Gerard, A. (2002). Influences of triploidy, parentage and genetic diversity on growth of the Pacific oyster Crassostrea gigas reared in contrasting natural environments. Mol. Ecol. 11, 1499-1514.

Guo, X., Debrosse, G.A. \& Allen, S.K.Jr. (1996). All triploid oysters (Crassostrea gigas Thunberg) produced by mating tetraploids and diploids, Aquaculture, 142: 149-161.

Janssen, J.A.M. \& J.H.J. Schaminée (2009). Europese natuur in Nederland. Natura 2000-gebieden van Zee en Kust. Zeist, KNNV Uitgeverij.

Jongbloed, R.H., A.C. Smaal, C.J. Smit, M. Poelman, A.G. Brinkman, N.M.J.A. Dankers, I.G. de Mesel \& J.A. van Franeker (2009). Ecologische analyse van potentiële locaties voor mosselzaadinvang (MZI) in Nederlandse kustwateren IMARES Rapport C088/09.

Kamermans, P., M. Poelman \& M.Y. Engelsma (2013). Oesterherpesvirus: een overzicht. IMARES, Rapportnummer: Factsheet, 2 pagina's.

Kamermans, P., C. Smit, J. Wijsman \& A. Smaal (2014). Meerjarige effect- en productiemetingen aan MZI's in de Westelijke Waddenzee, Oosterschelde en Voordelta: samenvattend eindrapport. IMARES Rapport C191/13.

Kamermans P. \& Smaal A. (2014). Passende Beoordeling (PB) mosselzaadinvang (MZI) op vrije gronden in de Nederlandse kustwateren voor de periode 2015-2018. IMARES Rapport C168/14.

Kamermans P. (2015). Triploïde Japanse oesters: een overzicht. IMARES Factsheet, 2 pagina's

Kamermans P. \& M. van Asch (2018). Monitoring draagkracht voor schelpdieren in relatie tot opschaling MZIs in de Waddenzee en Oosterschelde. IMARES Rapport C043/18.

Kamermans P. \& A. Smaal (2016). Passende beoordeling ten behoeve van experimentele oesterkweek in het sublitoraal van de Kom van de Oosterschelde. IMARES rapport C013/16.

Kamermans P. (2017). Passende Beoordeling ten behoeve van experimentele oesterkweek op Windgat percelen in de Kom van Oosterschelde. Wageningen University \& Research rapport C031/17

Krijgsveld K.L., R.R. Smits \& J. van der Winden (2008) Verstoringsgevoeligheid van vogels. Update literatuurstudie naar de reacties van vogels op recreatie. Bureau Waardenburg/Vogelbescherming Nederland rapport nr. 08-173.

Lapègue S., P. Boudry \& P. Goulletquer (2008). Pacific cupped oyster - Crassostrea gigas. Genimpact final scientific report.

Mesel I. De, Meesters H.W.G., Meijboom A. \& Wijsman J.W.M. (2008). Impact van MZI's op organische koolstof in de bodem. IMARES Rapport C037/08.

Ministerie van LNV (2004). Ruimte voor een zilte oogst. Naar een omslag in de Nederlandse schelpdiercultuur. Beleidsbesluit Schelpdiervisserij 2005 - 2020. Ministerie van Landbouw, Natuur en Voedselkwaliteit, Rapport, 46 pagina's.

Ministerie van LNV (2009). Definitief aanwijzingsbesluit Natura 2000-gebied Oosterschelde. Ministerie van Economische Zaken, Landbouw en Innovatie, Rapport.

Ministerie IenM (2016). Natura 2000 Deltawateren Beheerplan Deltawateren 2016-2022 Oosterschelde, Ministerie van Infrastructuur en Milieu | Rijkswaterstaat. Rapport, 104 pagina's. 
Nell J.A. \& Perkins B. (2005). Studies on triploid oysters in Australia: farming potential of all-triploid Pacific oysters Crassostrea gigas (Thunberg), in Port Stephens, New South Wales, Australia. Aquac Res 36:530-536.

NOV (2016) Plan van Aanpak 'Oester-maatregelen' 2016 - 2018.

Reed, D.H.J., J. O'Grady, B.W. Brook, J.D. Ballou \& R. Frankham (2003). Estimates of minimum viable population sizes for vertebrates and factors influencing those estimates. Biological Conservation 113: 23-34.

Robert, R.J.L. Sanchez, L. Perez-Paralle, E. Ponis, P. Kamermans, M. \& O'Mahoney (2012). A glimpse of the mollusc industry in Europe. Aquaculture Europe 38: 5-11.

Smaal A.C., P. Kamermans \& W.J. Strietman (2016). Kennis en onderzoeksagenda voor de Nederlandse oestersector. IMARES Rapport C057/16.

Smaal A.C., T. Schellekens, M.R. van Stralen \& J.C. Kromkamp (2013). Decrease of the carrying capacity of the Oosterschelde estuary (SW Delta, NL) for bivalve filter feeders due to overgrazing? Aquaculture 404-405: 28-34.

Stanley, J.G., H. Hidu \& S.K. Allen Jr. (1984). Growth of American oysters increased by polyploidy induced by blocking meiosis I but not meiosis II. Aquaculture 37: 147-155.

Strietman, W.J., A. Smaal \& B. Bolman (2016). Economische situatie van de oestersector. Potentiele impact van herpesvirus in oesters en Japanse oesterboorder op de oestersector. Quickscan, LEI.

Troost, K. \& H. Van Hulzen (2009). Doelendocument Natura 2000 Deltagebied. Uitwerking van Natura 2000 waarden in omvang, ruimte en tijd, Rapport, 233 pagina's.

Van Bentum, D. \& E. Koolmees (2014). Natura 2000-ontwerpbeheerplan Deltawateren 2015-2021 Oosterschelde (5e concept). Royal Haskoning DHV, Rapport, 69 pagina's.

Van den Ende D., M. van Asch, E.B. Brummelhuis \& K. Troost (2014). Japanse oesterbanken op droogvallende platen in de Nederlandse kustwateren in 2014: bestand en arealen. IMARES Rapport: C172/14

Van den Ende, D., E. Brummelhuis, C. Van Zweeden, M. Van Asch \& K. Troost (2016). Mosselbanken en oesterbanken op droogvallende platen in de Nederlandse kustwateren in 2015: bestand en arealen, Rapport nummer: IMARES rapport C168/15, 45 pagina's.

Van Maldegem, D. (2004). Ontwikkeling morfologie Oosterschelde in relatie tot zandhongerproblematiek; RIKZ/AB/2004.809x; juli 2004.

Van Stralen, M.R., K. Troost \& A. Gitttenbrerger (2015). Vindplaatsen oesterboorders, najaar 2015. Memo PO Mosselcultuur.

Wegner A., E. Besseling, E.M. Foekema, P. Kamermans \& A.A. Koelmans (2012). Effects of Nanopolystyrene on the Feeding Behaviour of the Blue Mussel (Mytilus edulis L.). Environmental Toxicology and Chemistry 31: 2490-2497.

Wijsman, J.W.M. \& P.C. Goudswaard (2015). Passende Beoordeling vaste vistuigvisserij in de Oosterschelde. Wageningen IMARES, Rapport nummer: C127/15, 69 pagina's. 


\section{Verantwoording}

Rapport C064.18

Projectnummer: 4313200001

Dit rapport is met grote zorgvuldigheid tot stand gekomen. De wetenschappelijke kwaliteit is intern getoetst door een collega-onderzoeker en het verantwoordelijk lid van het managementteam van Wageningen Marine Research

Akkoord:

Dr. R.H. Jongbloed

Onderzoeker

Handtekening:

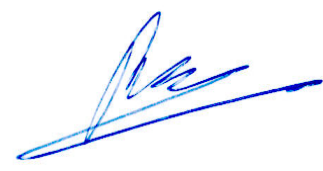

Datum:

6 september 2018

Akkoord:

Drs. J. Asjes

MT lid integratie

Handtekening:

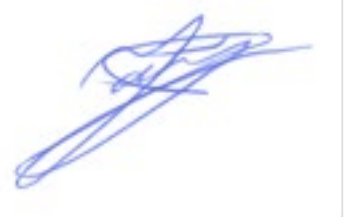

Datum:

6 september 2018 


\section{Bijlage 1 Factsheet triploïde oesters}

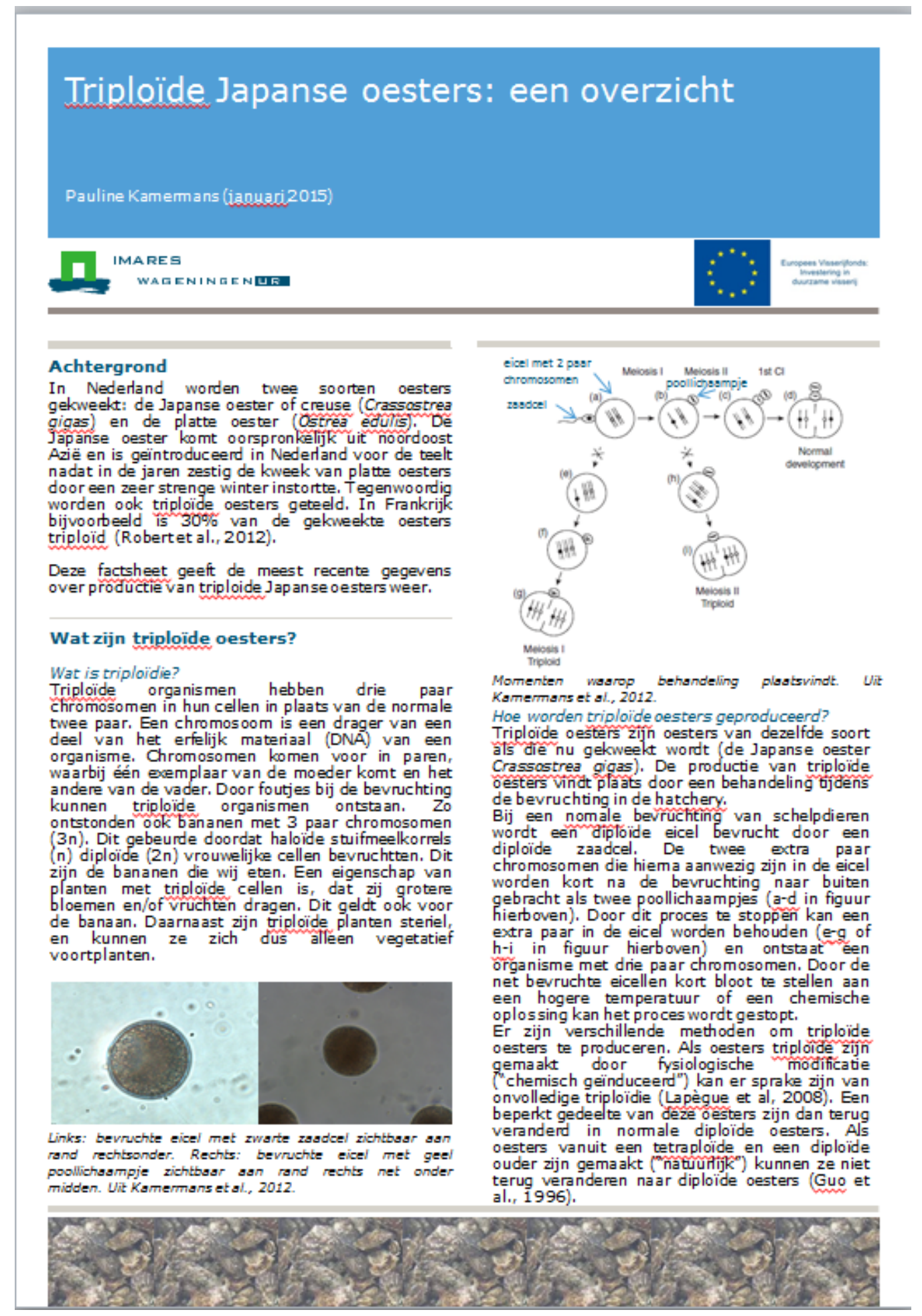




\section{Innovaties}

Waarom worden triploide oesters geproduceerd? Door het extra paar chromosomen zijn triploïde oesters steriel. Omdat geen energie wordt gebruikt voor het ontwikkelen van geslachtsorganen en voor het ontwikelen van geslachiorganen en producten kunnen triploide oesters sneler groeien (Stanley, et al, 1984; Nel \&. Perkins, 2005). pariode dat andere oesters paaien gewicht verliezen (Nell \&. Perkins, 2005; Boudry, 2008). Dit zorgt ervoor dat triploide oesters ook in de zomer verkocht kunnen worden. Ook zijn trioloïde oesters beter resistent tegen stressvolle condities (GamierGere et al., 2002) en vertonen ze een lagere sterfte (Gagnaireet al., 2006).
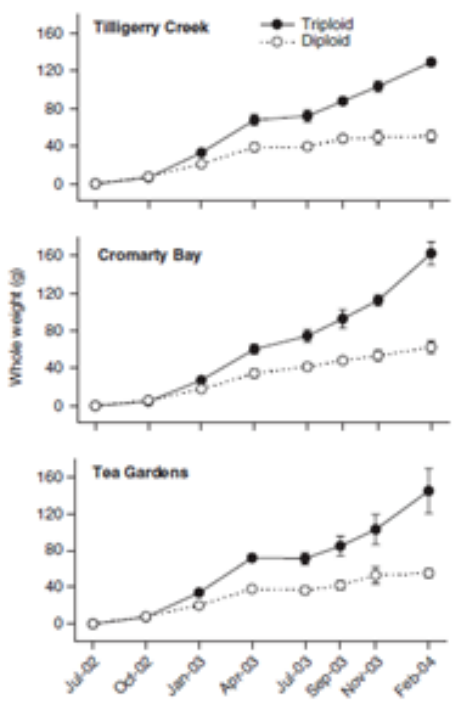

Groei van Japanse briploide en diploide oesters in Port Stevens, Australie. Uit Neil \& Perkins, 2005.

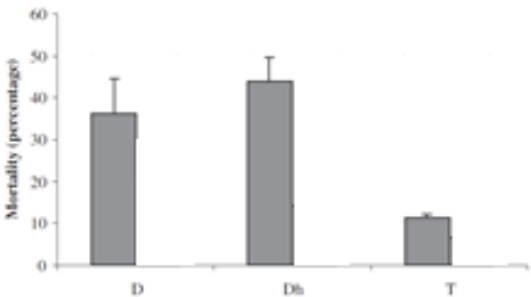

Sterfte percentage van in het wild opgevangen oesters (D). hatehery geproduceerde oesters (Dh) en briploids oesters (T) gekweekt van mast tot september 2002 in zakken op tafels in Marennes-Qleron, Frankrijk. U/L Gagnaire et at., 2006.

\section{Onderzoek}

In 2014 is het project Ontwikkeling triploide oester voor Yerseke gestart. Het project wordt gefinancierd in het kader van de subsidieregeling Operationeel Programma "Perspectief voor een duurzame Visserij" In dit project werkt de Roem van Yerseke BV samen met Bonton Products BV, Prins \&. Dingemanse BV en IMARES. De hatchery van de Roem van Yerseke za triploide en diploid oesterbroed produceren. IMARES begeleidt de proef. De groei, overleving en kwaliteit van triploïde en diploïde oesters wordt vervolgens vergeleken in mandjes en zakken in de Oosterschelde. Roem van Yerseke, BV, Bonton Products BV en Prins \&. Dingemanse BV zullen de oesters in het veld monitoren.

\section{Referenties}

Boudry, P. (2008) Review on Bresding and Reproduction of Europesn aquaculture species Pacific oyster (Craseostres gigas). Aqus Breeding report.

Gagnaire B, P Soletehnik, PM adec, P Geaino, OL- Moine, T Renault (2006) Diploidand triploid Pacificoysters, Crassostrea gigss (Thunberg), reared at two heights Qbovesediment in Marennes-Oleron Basin, Frana: Difference in mortality, sexual maturation and hemocyte parameters. Aquaculture 254: 606-616.

Garnier-Gere, P.A., Naciri-Graven, Y., Bougrier, S., Magoulas, A., Heral, M., Rotoulas, G., Hawkirs, A., Gerard, A. 2002. Influencess of triploidy, parentage and genetic diversity on grow th of the Pscific oyster Crasostres. gigas reared in contrasting natural enviroments. Mo. Ecol. 11, 1499-1514.

Gus, X., Debrosse, G.A. and Allen, S.K.Jr.,1996. All triploid oysters (Crassostres gigss Thunberg) produced by mating tetraploids and diploids, Aquaculture, 142 : 149-161.

Kamermars P, T Galley, P Boudry, J Fuentes, H MeCombie, F M. Batists, A Blsnco, LDominguez, F Cornette, L Pincot, 8. A Besumont (2013). Blus musse' hatehery technology in Europe. In: Advances in aquaculture hatehery technology. Woodhead Publishing Cambrolge, pp 339-373

Lapègue S., P. Boudry and P. Goulletquer (2008) Pacific cupped oyster - Crassostres gigas. Genimpact final scientific report.

Nell JA, Perkins B (2005) Studies on triploid oysters in Austra is: farming potential of all-triploid Pacific oysters Crassostrea gigss (Thunberg), in Port Stephens, New South Wales, Australis. Aquac $R=36: 530-536$

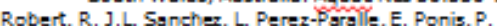
Kamermars, M. O'Mahoney (2612) Aglimpse of the molluse industry in Europe. Aqusculture Europe 38: 5

Stanley, J. G., H. Hidu and S. K. Allen, Jr. 1984. Grow th of American oysters incressed by polyploidy induced by blocking meiosis I but not meicsis II. Aquaculture 37 : 147-155.

\section{Nawoord}

In deze factsheet hebben we getracht een zo compleet mogelijk overzicht te geven van de huidige stand van zaken rondom triploide oesters. Echter de ontwikkelingen gaan snel, Topende onderzoken kunnen nieuwe inzichten geven. Het is belangrijk deze nieuwe ontwikkelingen te stimuleren en te blijven volgen.

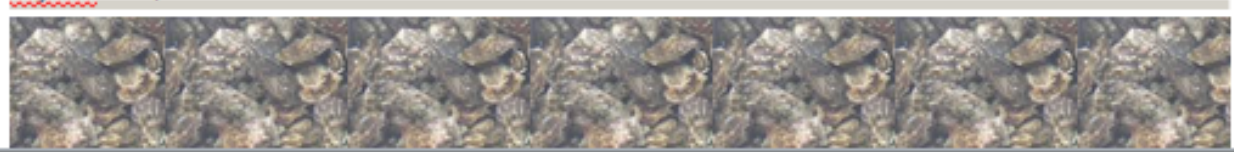




\section{Bijlage 2 Begeleiding OesterKweek eXperimenten (BOKX)}

Eind maart 2016 heeft IMARES (nu WMR genaamd) een convenant gesloten met o.a. de Nederlandse Oestervereniging. In het kader daarvan is in juli 2016 het project Begeleiding Oesterkweek eXperimenten (BOKX) gestart en een werkplan opgesteld. Onderdeel daarvan is monitoring ten behoeve van vergunning voor off-bottom experimenten in de Oosterschelde. Dit betreft:

a. WMR rapporteert het relatieve verschil in scheepsbewegingen en verbruik van gasolie tussen offbottom kweek en bodemcultuur. Kwekers leveren gegevens aan. WMR zal zorgdragen voor validatie van de gegevens door een vergelijking met informatie uit andere landen uit te voeren. De resultaten zullen worden teruggekoppeld aan de werkgroep off-bottom oesterteelt.

b. Voor de aanwezigheid van beschermde vogelsoorten op en nabij de experimenten in vergelijking met aanwezigheid op bodempercelen wordt een identificatie protocol opgesteld. Ook zal instructie aan boord plaatsvinden door WMR medewerkers. Daarnaast zal WMR tellingen uitvoeren op dagen dat de kwekers wel en niet aan het werk zijn. Hierbij kan gebruik gemaakt worden van cameraopstellingen. De resultaten zullen worden teruggekoppeld aan de werkgroep off-bottom oesterteelt. De onderzoeksvraag betreft: Is er verschil in aanwezigheid van beschermde vogelsoorten op en nabij de experimenten tijdens het uitvoeren van werkzaamheden en bij afwezigheid van werkzaamheden in vergelijking met aanwezigheid van vogels op bodempercelen bij aan- en afwezigheid van werkzaamheden?

c. Een systematische monitoring van de groei en sterfte van een groep uniforme oesters die op verschillende plaatsen zijn uitgezet kan een beeld geven van het succes van off-bottom teelt in vergelijking met bodemcultuur. WMR kan voor de monstername een protocol voor de kwekers opstellen en de monsters van off-bottom teelt en bodemcultuur analyseren. Na iedere monstername kunnen de resultaten worden teruggekoppeld aan de werkgroep off-bottom oesterteelt.

Indien de vergunning voor de kweekactiviteiten wordt verleend, kan de monitoring daarvan ook worden opgenomen. Dit betreft dan naast bovengenoemde metingen ook onderzoek naar consequenties van kooien en tafels met zakken met betrekking tot 'leefgebied en soorten' (verandering slibgehalte). 


\section{Bijlage 3 AERIUS Calculator resultaten voor het verwachte stikstofuitstoot tijdens werkzaamheden op dit project.}

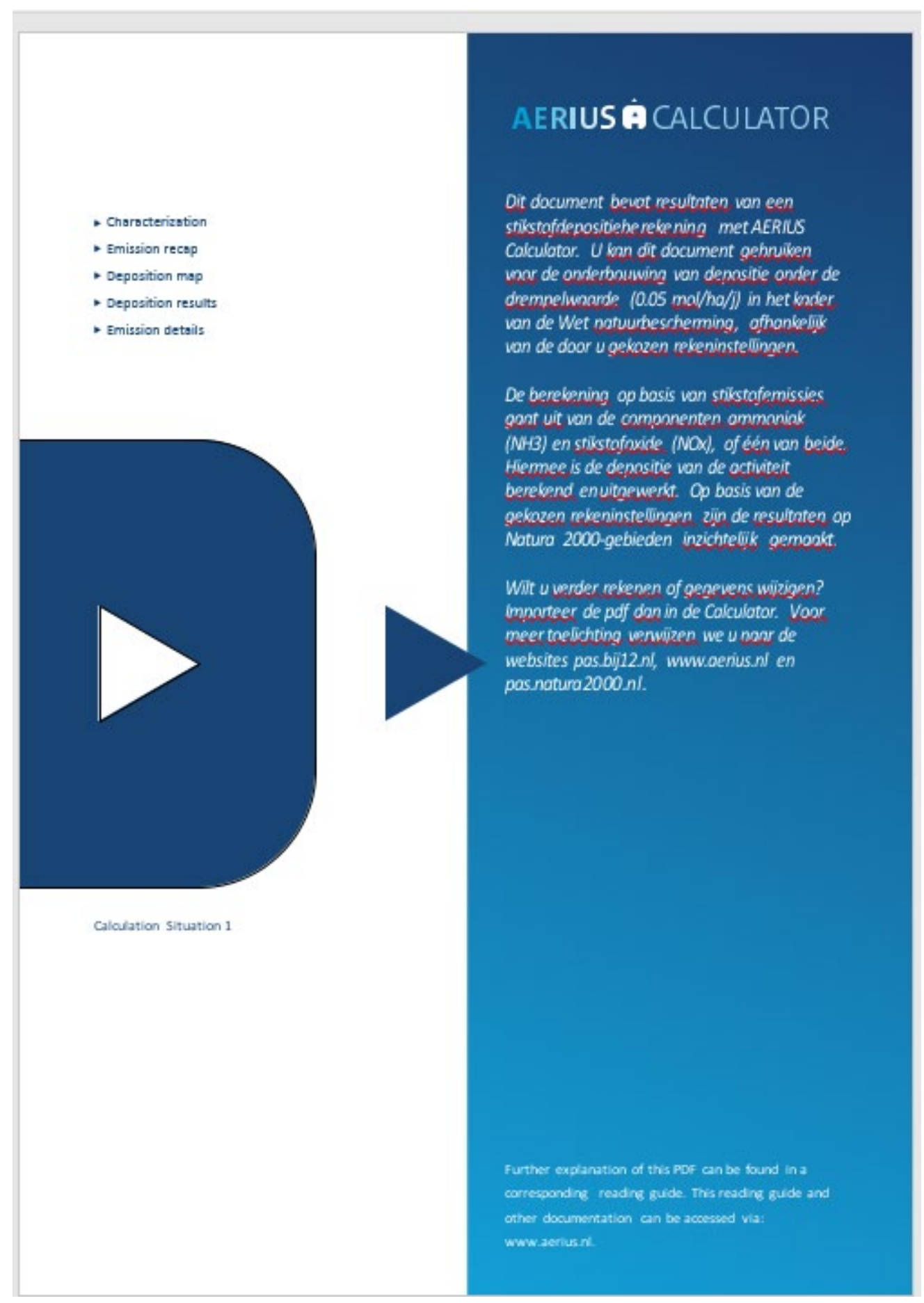


Calculation for own use

\section{AERIUS Á CALCULATOR}

\begin{tabular}{|c|c|c|c|}
\hline Contact & Leplestity & Fadity location & \\
\hline & - & - & \\
\hline Activity & Description & & \\
\hline & - & RZ5XBPEWutLr & \\
\hline & Cuculation dane & Calculntion year & Caloulnition aptions \\
\hline & 21 June $2018,14: 94$ & 2018 & Colculated with \\
\hline
\end{tabular}

Total emission

\begin{tabular}{|c|c|c|c|}
\hline & & Sthuation 1 & \\
\hline & NOx & $17,651.62 \mathrm{~kg} / \mathrm{y}$ & \\
\hline Results & $\mathrm{NH3}$ & - & \\
\hline $\begin{array}{l}\text { Hectore with } \\
\text { highest }\end{array}$ & & & \\
\hline 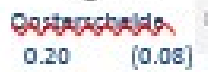 & Nanure arso & & Contribusion \\
\hline
\end{tabular}

Clarification 


\section{AERIUS Ṗ CALCULATOR}

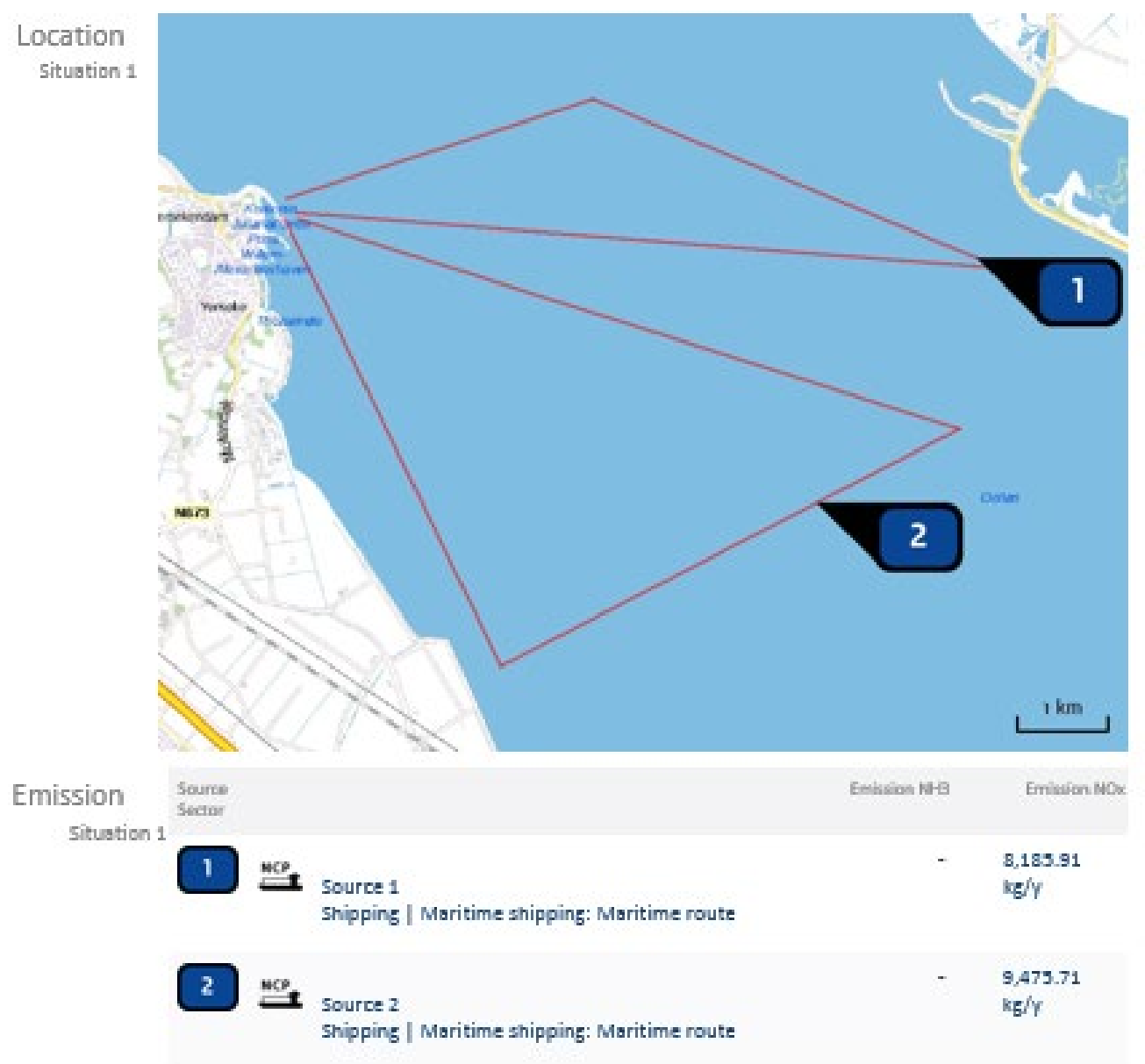




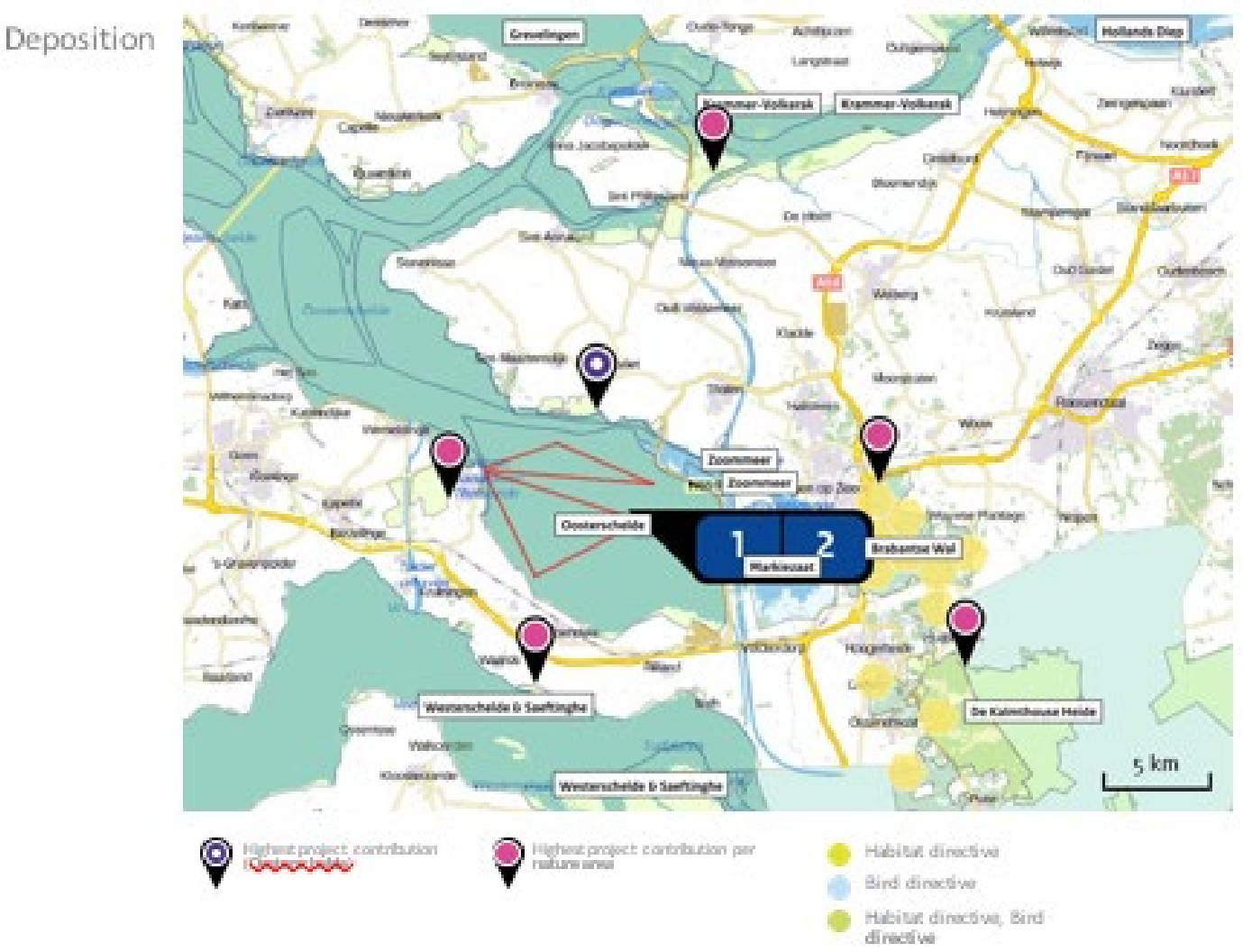


AERIUS Á CALCULATOR

\begin{tabular}{|c|c|c|}
\hline \multirow{2}{*}{$\begin{array}{r}\text { Results NCA } \\
\text { areas } \\
\text { (5ow/ha/y] }\end{array}$} & Aeva & Highest coetr bution" \\
\hline & Gosterectebelda & $0.20(0.08)$ \\
\hline & Brabatse, Wal & 0.10 \\
\hline & 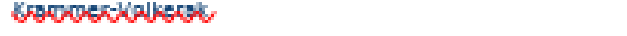 & 0.06 \\
\hline & 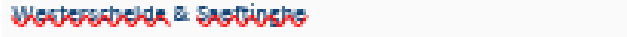 & $0.06(-)$ \\
\hline & 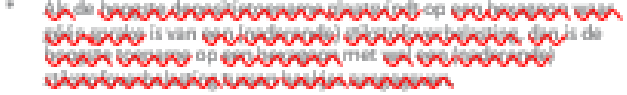 & \\
\hline
\end{tabular}

Calculation for own use 


\section{AERIUS A CALCU LATOR}

Results per Qosterschelde habitat kook/ha/r)

$$
\text { Habian sipe }
$$

Highest contr bution *

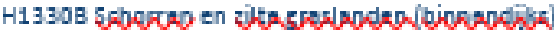

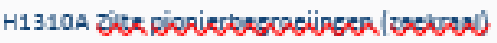

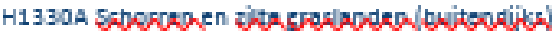

H1320 Sh kERosuglder

\}rackantse Wal

Habitan sypa

Highest contr bution *

LF13 Bos van erope wodsceader

0.10

L4030 DRgGa beide0.

0.10

L509 Progs fruiceraluod,

0.10

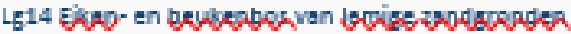

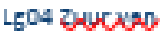

H9190 Oude ejkapbazKan.
$0.20(-)$

$0.20(20.05)$

0.08

0.08
0.08

0.06 


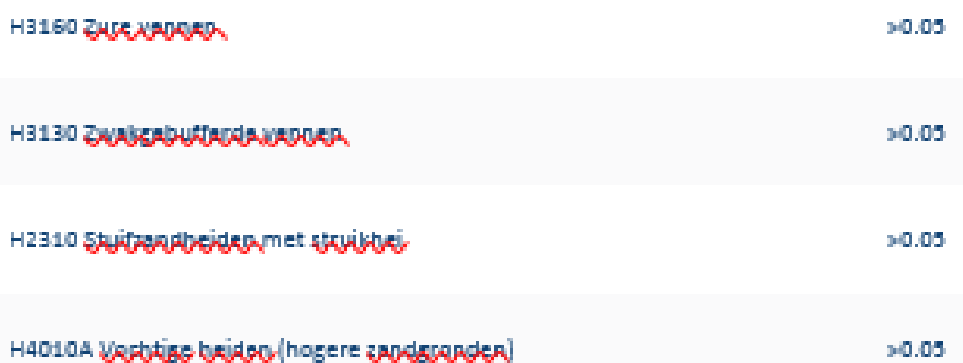

\section{Krammer-Volkerak}

Habitan spe

Highest contribution *

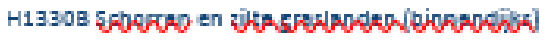

0.06

H2190B Vacbise dripuehbipo-[kalkjik]

0.06

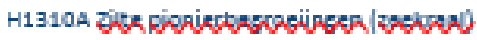

0.06

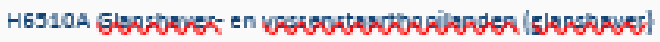

$30.05(-)$

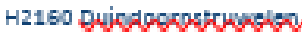

30.05

Nesterschelde \& Saeftinghe

Habitan sype

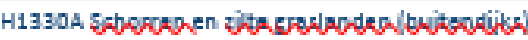

Hithest contrifion *

$0.06(-)$

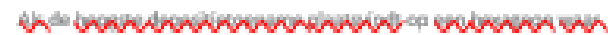

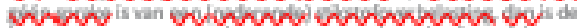

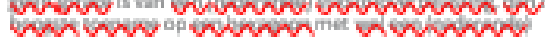

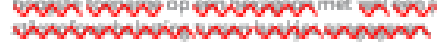




\section{AERIUS Á CALCULATOR}

Calculation for own use

Results

Aswa

Highest contr bution *

remaining

areas

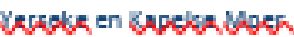

$0.13(-)$

(ood/ha/ / ]

Salpothoutes Heide

$0.06(-)$

De Galpothorge, Heide

$0.06(-)$

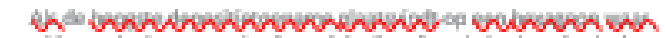

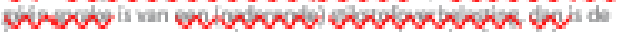

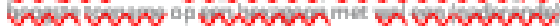

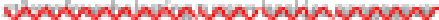


AERIUS Á CALCULATOR

Results per Yerseke en Kapelse, Moer habitat

(ooliha/r)

\author{
Kalpothoutse Heide
}

De Kalmothouse Heide

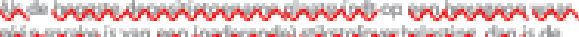

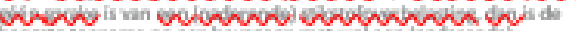

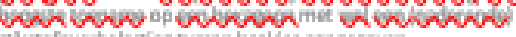


(by)

Situation 1

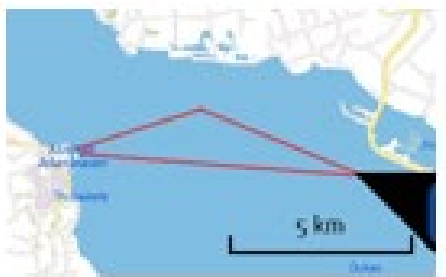

5hip type

Description

Bealschepera en Visserscheped GT 100-1999
Ecoissienewne Source 1 source) Loonion $(x, y) 70282,390522$

no

\section{$8,185.91 \mathrm{~kg} / \mathrm{y}$}

Number of visits Unt sown

Embision

390 Nor

$8,183.91$

$\mathrm{kg} / \mathrm{Y}$

Disclaimer

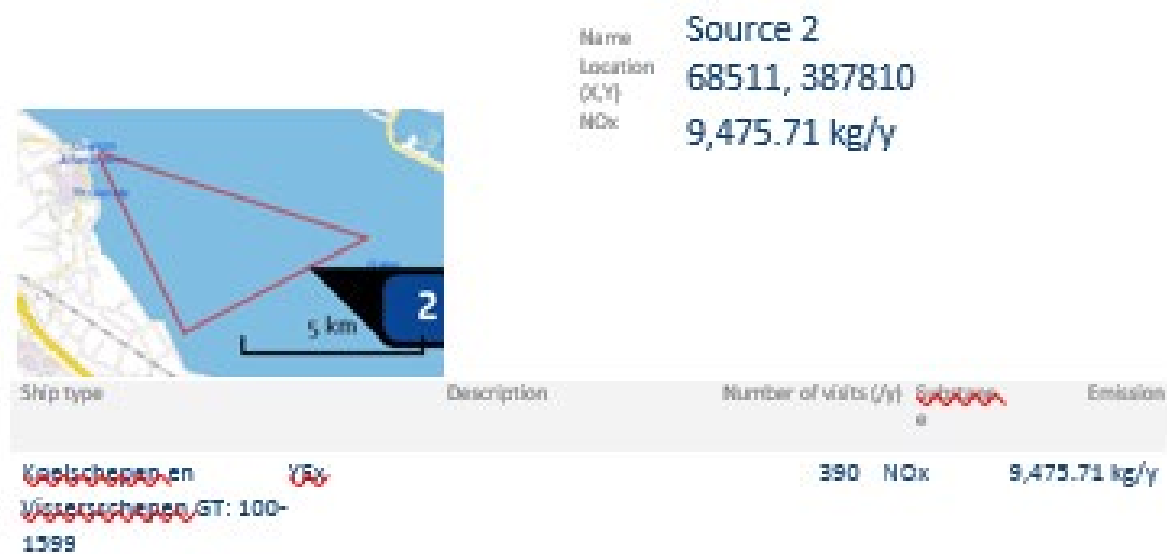

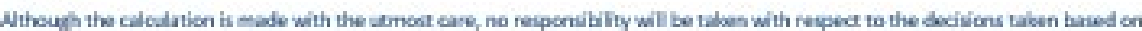

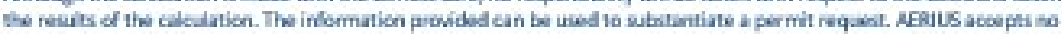

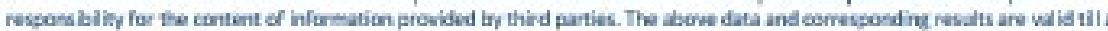

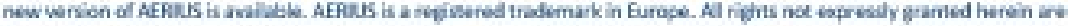
reserved

References for This calculation is bived co:

calculations

NEAUS verion 20161,20171215,64190d2d2t

Ounabase wersion 2018.20170328_amsetoof

For more infor matios abous the methodol oty and data sev:

https:/mwwaeriusal/ni/lactsheets/uitiog 


\section{Bijlage 4 Vogeltellingen telgebied RWS OS532}

(Broek) in de periode $2013 \mathrm{t} / \mathrm{m} 2016$. Vogeltellingen

werden in de maanden maart, april, juni, juli,

september en oktober maandelijks geteld (data

servicedesk RWS).

Bontbekplevier

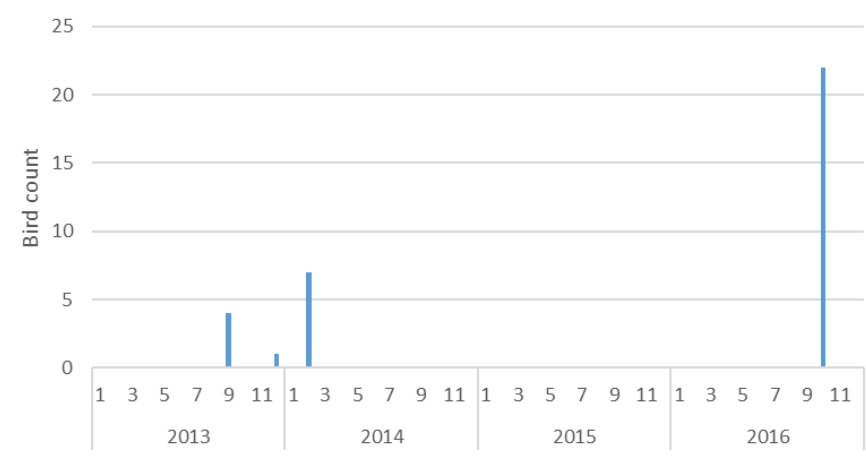

Drieteenstrandloper
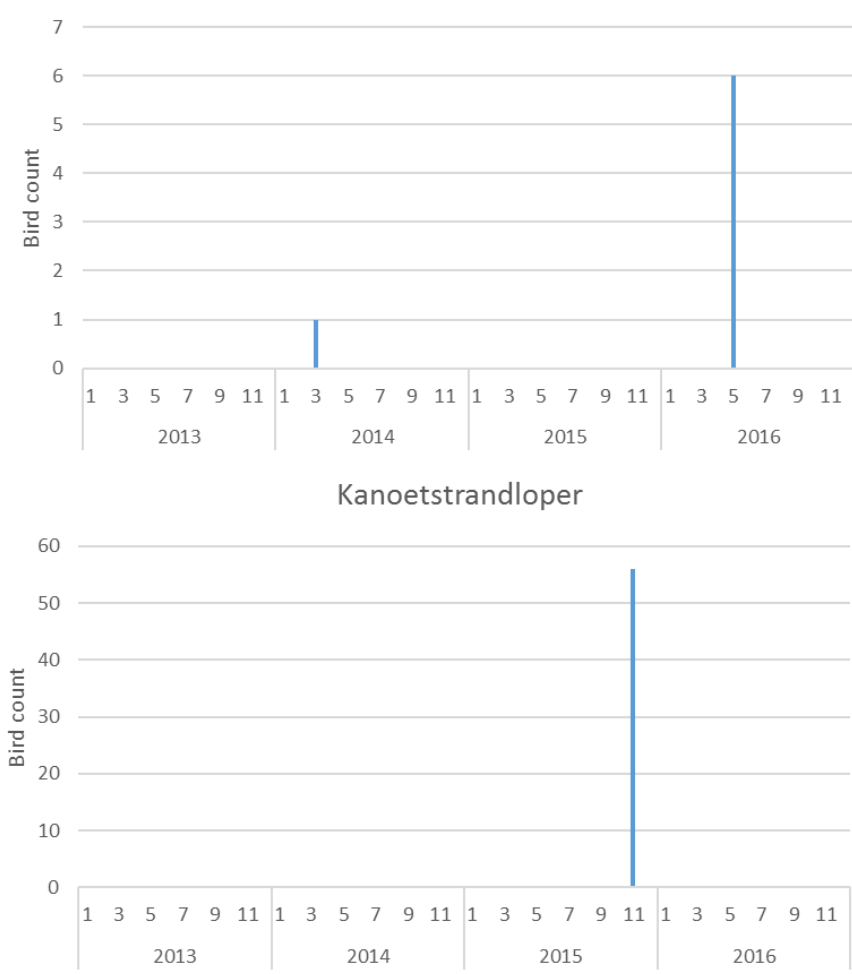

Bonte Strandloper
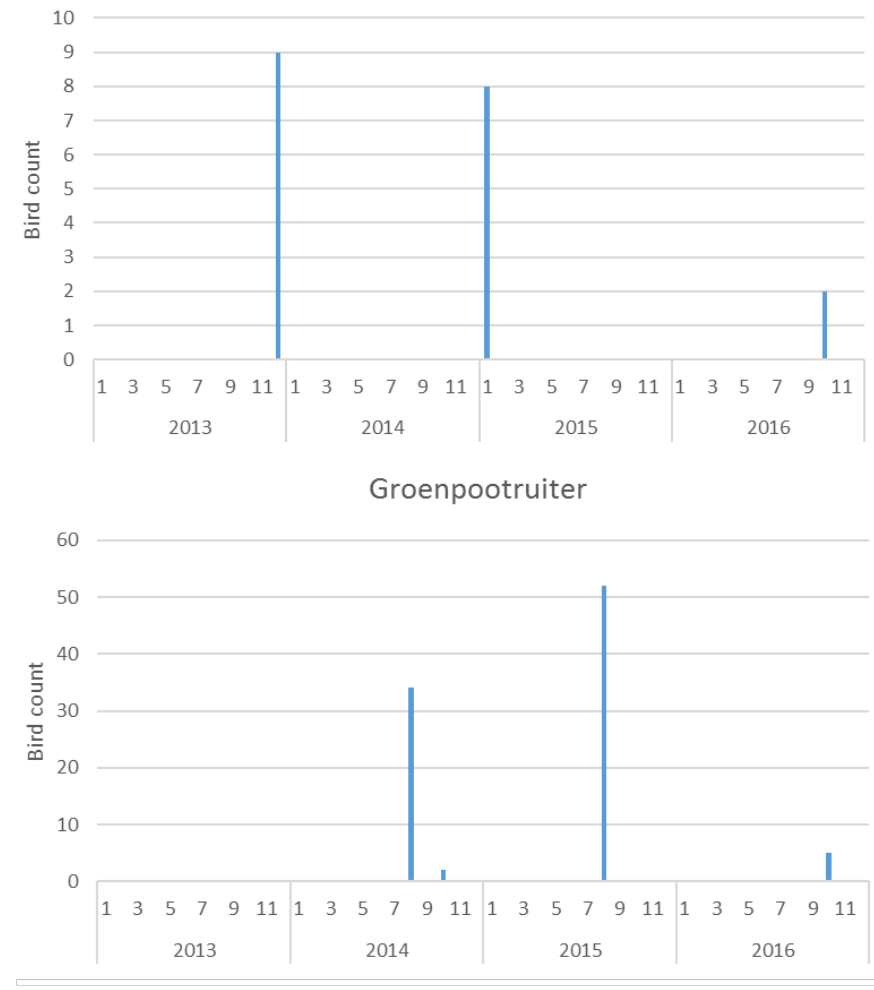

Rosse Grutto

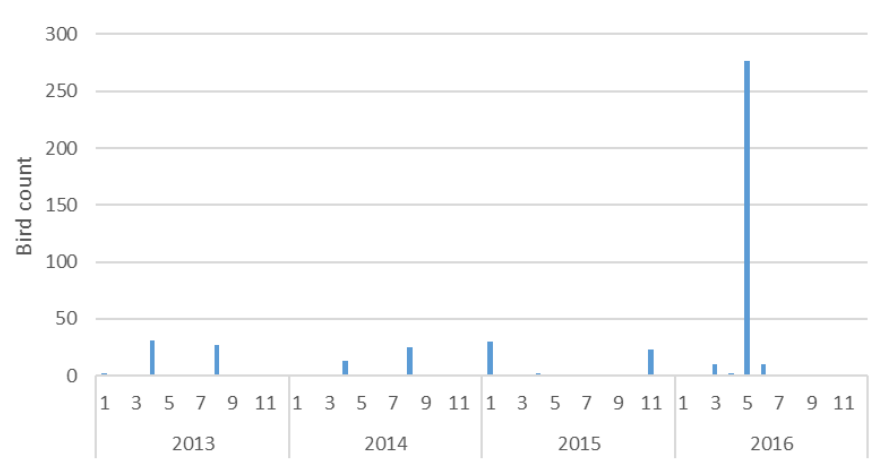



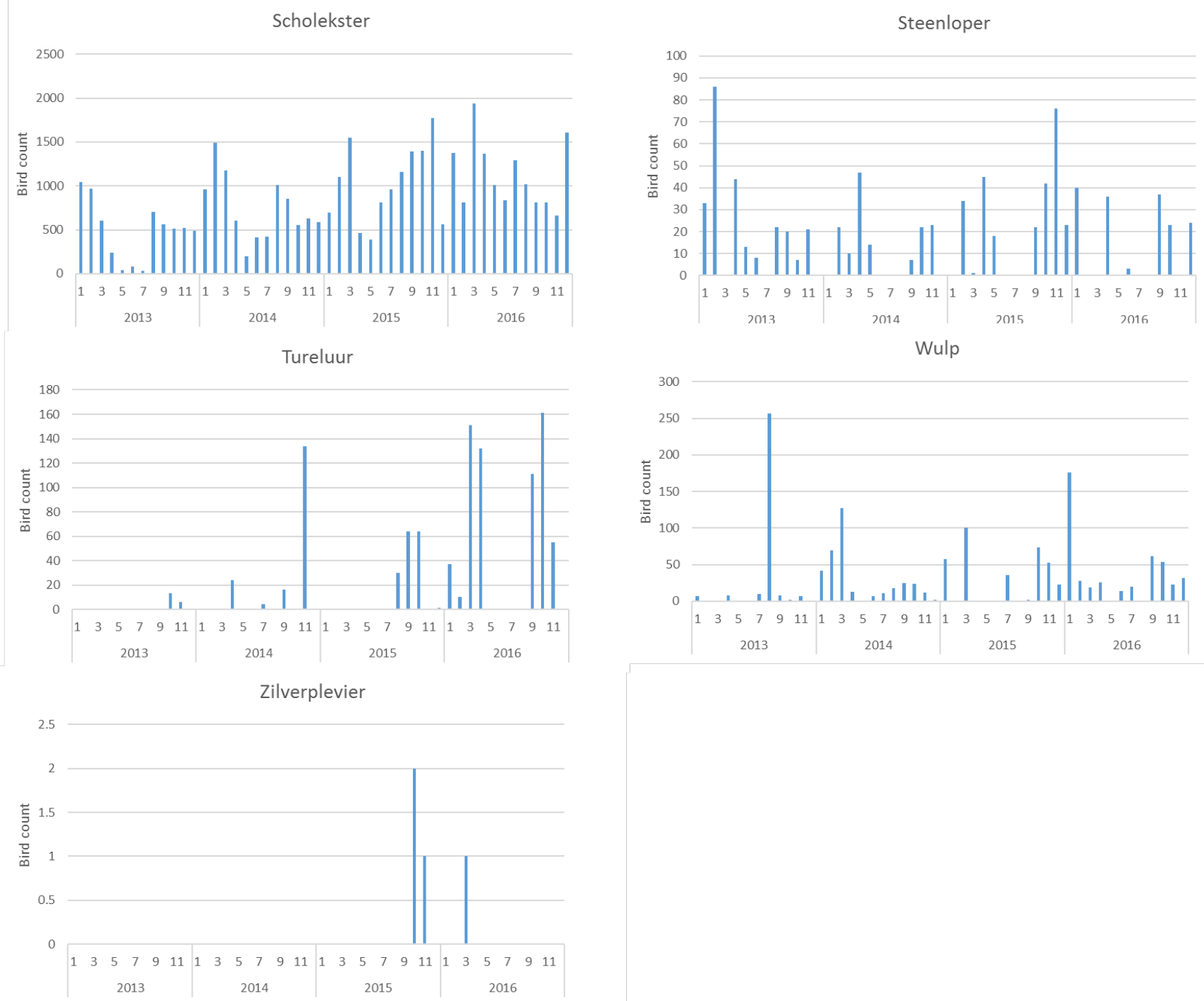


\section{Bijlage 5 Vogeltellingen telgebied RWS OS630}

(Yerseksche Oesterbank) in de periode $2013 \mathrm{t} / \mathrm{m}$ 2016. Vogeltellingen werden in de maanden maart, april, juni, juli, september en oktober maandelijks geteld (data servicedesk RWS).

Bontbekplevier

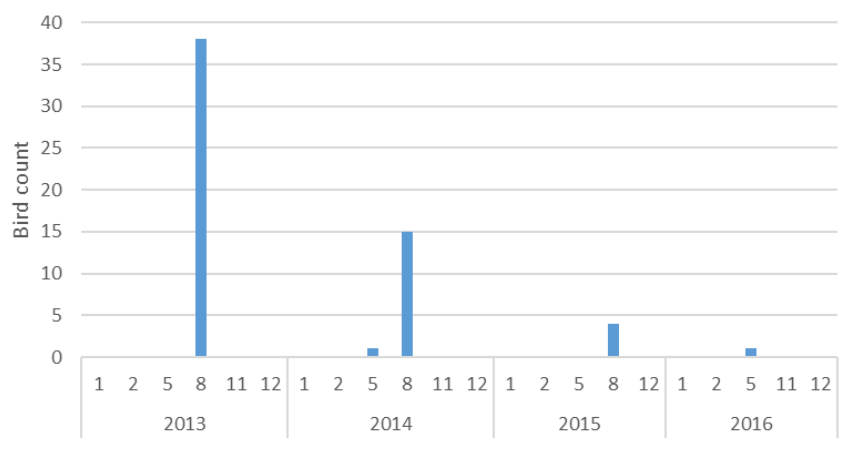

Groenpootruiter

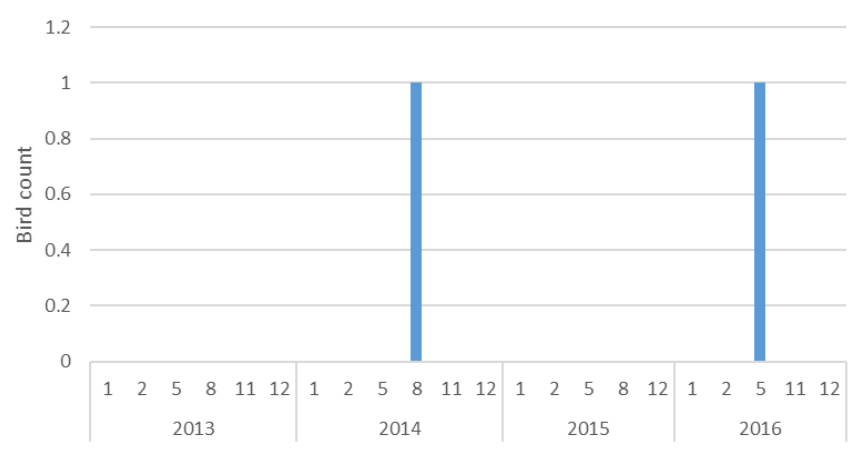

Scholekster

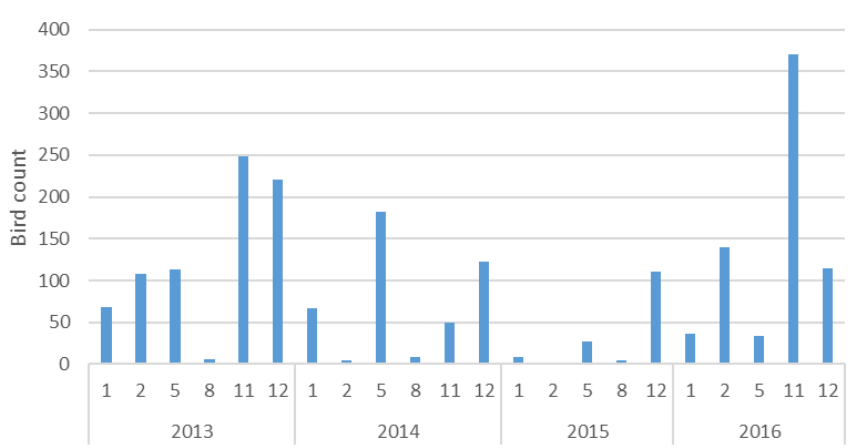

Bonte Strandloper

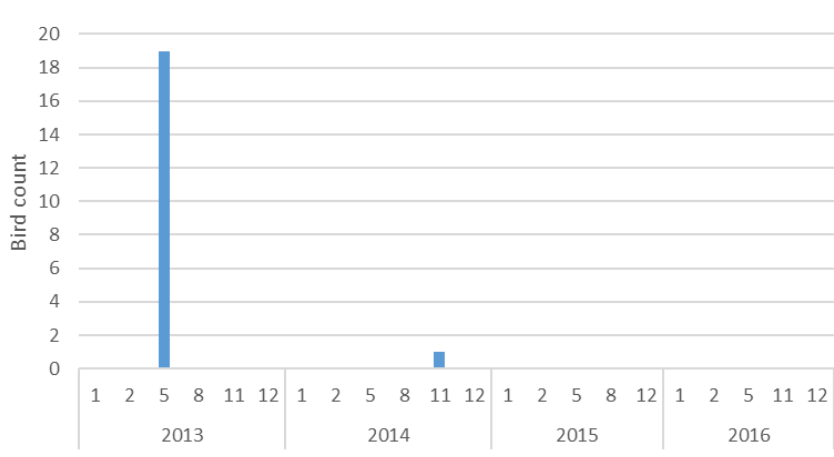

Rosse Grutto

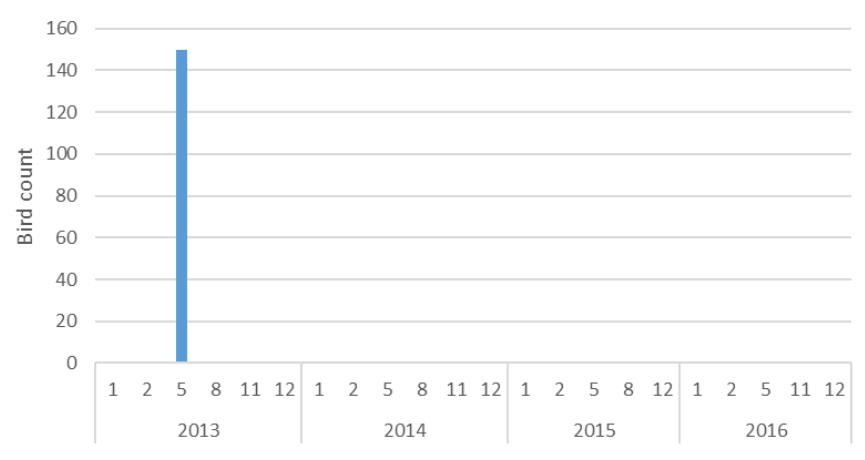

Steenloper

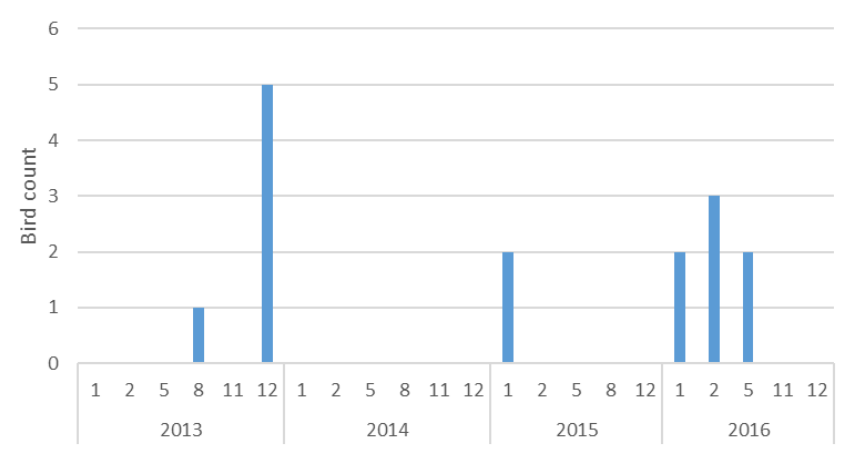


T: +31(0)317480900

E: marine-research@wur.nl

www.wur.nl/marine-research

Visitors address

- Ankerpark 271781 AG Den Helder

- Korringaweg 5, 4401 NT Yerseke

- Haringkade 1, 1976 CP IJmuiden established to provide the scientific support that is essential for developing policies and innovation in respect of the marine environment, fishery activities, aquaculture and the maritime sector.

Wageningen University \& Research is specialised in the domain of healthy food and living environment.

\section{The Wageningen Marine Research vision:}

'To explore the potential of marine nature to improve the quality of life.'

\section{The Wageningen Marine Research mission}

- To conduct research with the aim of acquiring knowledge and offering advice on the sustainable management and use of marine and coastal areas.

- Wageningen Marine Research is an independent, leading scientific research institute.

Wageningen Marine Research is part of the international knowledge organisation Wageningen UR (University \& Research centre). Within Wageningen UR, nine specialised research institutes of Stichting Wageningen Research (a Foundation) have joined forces with Wageningen University to help answer the most important questions in the domain of healthy food and living environment. 